\title{
The CHRONOS mission: capability for sub-hourly synoptic observations of carbon monoxide and methane to quantify emissions and transport of air pollution
}

\author{
David P. Edwards ${ }^{1}$, Helen M. Worden ${ }^{1}$, Doreen Neil ${ }^{2}$, Gene Francis ${ }^{1}$, Tim Valle ${ }^{3}$, and Avelino F. Arellano Jr. ${ }^{4}$ \\ ${ }^{1}$ National Center for Atmospheric Research (NCAR), Boulder, CO, USA \\ ${ }^{2}$ NASA Langley Research Center, Hampton, VA, USA \\ ${ }^{3}$ Ball Aerospace, Boulder, CO, USA \\ ${ }^{4}$ Department of Hydrology and Atmospheric Sciences, University of Arizona, Tucson, AZ, USA
}

Correspondence: David P. Edwards (edwards@ucar.edu)

Received: 15 June 2017 - Discussion started: 28 June 2017

Revised: 21 December 2017 - Accepted: 3 January 2018 - Published: 23 February 2018

\begin{abstract}
The CHRONOS space mission concept provides time-resolved abundance for emissions and transport studies of the highly variable and highly uncertain air pollutants carbon monoxide and methane, with sub-hourly revisit rate at fine $(\sim 4 \mathrm{~km})$ horizontal spatial resolution across a North American domain. CHRONOS can provide complete synoptic air pollution maps ("snapshots") of the continental domain with less than $10 \mathrm{~min}$ of observations. This rapid mapping enables visualization of air pollution transport simultaneously across the entire continent and enables a sentinel-like capability for monitoring evolving, or unanticipated, air pollution sources in multiple locations at the same time with high temporal resolution. CHRONOS uses a compact imaging gas filter correlation radiometer for these observations, with heritage from more than 17 years of scientific data and algorithm advances by the science teams for the Measurements of Pollution in the Troposphere (MOPITT) instrument on NASA's Terra spacecraft in low Earth orbit. To achieve continental-scale sub-hourly sampling, the CHRONOS mission would be conducted from geostationary orbit, with the instrument hosted on a communications or meteorological platform. CHRONOS observations would contribute to an integrated observing system for atmospheric composition using surface, suborbital and satellite data with atmospheric chemistry models, as defined by the Committee on Earth Observing Satellites. Addressing the U.S. National Academy's 2007 decadal survey direction to characterize diurnal changes in tropospheric composition, CHRONOS ob-
\end{abstract}

servations would find direct societal applications for air quality management and forecasting to protect public health.

\section{Introduction}

For the end of the current decade, geostationary Earth orbit (GEO) satellite missions for atmospheric composition are planned over North America, East Asia and Europe, with additional missions in formulation or proposed. Together, these present the possibility of a constellation of GEO platforms to achieve continuous, time-resolved, high-density observations of continental domains for mapping pollutant sources and variability on diurnal and local scales with nearhemispheric coverage (CEOS, 2011). In addition to NASA's TEMPO (Tropospheric Emissions: Monitoring Pollution) mission (Zoogman et al., 2017), the ESA/EUMETSAT (European Space Agency/European Organisation for the Exploitation of Meteorological Satellites) Sentinel-4 mission over Europe (GMES-GAS, 2009) and the Korean KARI (Korea Aerospace Research Institute) MP-GEOSAT/GEMS (Multi-Purpose Geostationary Satellite/Geostationary Environment Monitoring Spectrometer) mission over Asia (Lee et al., 2010) will provide data products for ozone $\left(\mathrm{O}_{3}\right)$, nitrogen dioxide $\left(\mathrm{NO}_{2}\right)$, sulfur dioxide $\left(\mathrm{SO}_{2}\right)$, formaldehyde $(\mathrm{HCHO})$ and aerosol optical depth (AOD) several times per day with smaller than $10 \mathrm{~km} \times 10 \mathrm{~km}$ spatial footprints. While these planned GEO measurements will provide new information 
on the diurnal evolution of emissions and chemical transformation of some important pollutants, they are missing observations of methane $\left(\mathrm{CH}_{4}\right)$ and carbon monoxide $(\mathrm{CO})$. As identified in CEOS (2011), these gases play key roles in atmospheric chemistry, air quality and climate.

The planned GEO constellation will be further enhanced by current and upcoming low Earth orbit (LEO) missions with atmospheric composition measurement capability. These missions include OMI (Ozone Monitoring Instrument; Levelt et al., 2006); IASI (Infrared Atmospheric Sounding Interferometer; Clerbaux et al., 2009); CrIS (Cross-track Infrared Sounder; Gambacorta et al., 2014); OMPS (Ozone Mapping Profiler Suite; Flynn et al., 2014); and the ESA Sentinel-5 precursor mission, TROPOspheric Monitoring Instrument (TROPOMI; Veefkind et al., 2012). The LEO assets allow for a transfer standard between the GEO missions, filling gaps in the spatial coverage, enabling crosscalibration and validation and, potentially, combined data products. Such an integrated global observing system for atmospheric composition is key to abatement strategies for air quality as prescribed in international protocols and conventions (e.g., IGACO, 2004).

Pollution affecting air quality is a complex mixture of many compounds that was designated a Group 1 carcinogen by the World Health Organization (WHO) (Loomis et al., 2013) amidst rising concerns about increased mortality and economic costs. Outdoor air pollution causes pulmonary and cardiovascular diseases, lung cancer and premature birth (Brunekreef and Holgate, 2002; M. C. Turner et al., 2015; Fann et al., 2012, Malley et al., 2017). Despite improvements in U.S. air quality in recent decades, present-day levels of air pollution are estimated to decrease average life expectancy by 0.7 years and contribute to $10 \%$ of the total deaths in highly polluted areas such as Los Angeles (Fann et al., 2012). In 2010 , over $3 \%$ of U.S. preterm births were attributed to air pollution at an estimated cost exceeding USD 5 billion (Trasande et al., 2016). To address the causes of air pollution effectively, decision makers need comprehensive measurements to quantify the full suite of pollutants, including $\mathrm{CH}_{4}$ and $\mathrm{CO}$, emitted from industrial, transport and energy sectors, as well as natural sources. $\mathrm{CO}$, which allows detection of combustion-related emissions, serves as the reference for the emissions of many difficult-to-measure pollutants that impact air quality and climate. Wildfires, which emit both $\mathrm{CO}$ and $\mathrm{CH}_{4}$, are a particular concern in the western U.S. (Abatzoglou and Williams, 2016), where burn areas have increased by a factor of 6 since 1970, with severe economic impacts (Westerling et al., 2006). $\mathrm{CO}$ and $\mathrm{CH}_{4}$ emissions also have significant consequences for climate change, especially considering $\mathrm{CH}_{4}$ pollution due to recent large increases in natural gas production (Pétron et al., 2012; Miller et al., 2013) and potential new $\mathrm{CH}_{4}$ releases from thawing permafrost (Ciais et al., 2013).

After air pollutants are emitted, they are transported vertically and horizontally in the atmosphere and can have a significant impact on local air quality and human health at locations near the sources and also downwind. Distinguishing the relative contributions of local and non-local pollution sources has emerged as a fundamental challenge for air quality management in the U.S. (NRC, 2004). Because CO has a medium lifetime (weeks to months), it can be transported globally, but it does not become evenly mixed in the troposphere. This moderate lifetime makes $\mathrm{CO}$ an ideal tracer of combustion-related air pollution (e.g., Edwards et al., 2004, 2006).

The CHRONOS mission is motivated by these fundamental questions regarding the emissions and transport of air pollutants. The CHRONOS gas filter correlation radiometry (GFCR) measurement technique for multispectral $\mathrm{CO}$ builds on 17 years of observations from the NASA Terra satellite Measurements of Pollution in the Troposphere (MOPITT) instrument (Drummond et al., 2010; H. M. Worden et al., 2013), in addition to experience in LEO column $\mathrm{CH}_{4}$ retrievals from SCIAMACHY (SCanning Imaging Absorption SpectroMeter for Atmospheric CHartographY; Frankenberg et al., 2005, 2011) and GOSAT (Greenhouse Gases Observing Satellite; Morino et al., 2011; Schepers et al., 2012). The CHRONOS temporal resolution (sub-hourly) and spatial resolution (nominally $4 \mathrm{~km} \times 4 \mathrm{~km}$ at the domain center) are required to capture the near-surface trace gas variability, as concluded by modeling and data studies performed by the Geostationary Coastal and Air Pollution Events (GEOCAPE) (Fishman et al., 2012) science team in response to the first decadal survey for Earth Science and Applications from Space (NRC, 2007). For $\mathrm{CH}_{4}$, the spatially and temporally dense CHRONOS measurements over the entire continental U.S. measurement domain would address the need for consistent assessments of $\mathrm{CH}_{4}$ emissions at decisionrelevant scales. For CO, proven multispectral retrieval techniques (Worden et al., 2010) increase the information on CO vertical distribution and can identify vertical transport from one observation to the next. Thus, CHRONOS is capable of tracking pollutants from the surface, where they are emitted, to where they degrade downwind air quality.

This paper describes the CHRONOS science, measurement technique, expected performance (precision and accuracy), retrieval vertical sensitivity and observing strategy. We then show how CHRONOS would complement observations from other current and planned satellite instruments, and we conclude with a summary of CHRONOS features and advantages.

\section{CHRONOS science}

\subsection{CHRONOS sub-hourly synoptic measurements with high spatial resolution}

Advances in tropospheric remote sensing from LEO over the past decade have shown the potential of satellites to quantify 
(a)

(b)

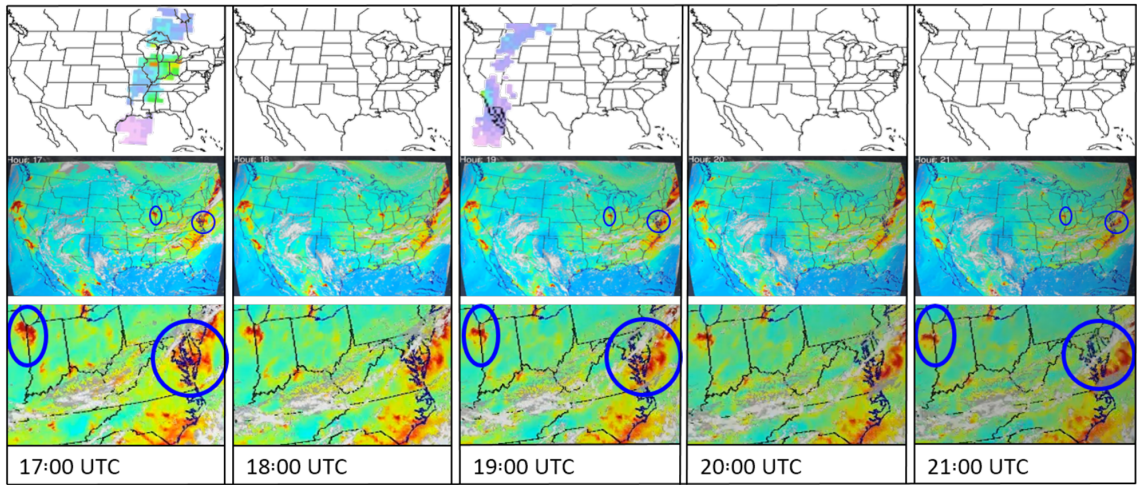

Figure 1. Comparison of MOPITT and simulated CHRONOS spatial and temporal coverage over a $5 \mathrm{~h}$ period on Tuesday, 1 August 2006. Top panels (a) show MOPITT retrievals of near-surface $\mathrm{CO}$ for each hour, with pink colors indicating low $\mathrm{CO}$ ( $\sim 60 \mathrm{ppbv})$ and green to red indicating higher values (200-300 ppbv). No MOPITT data were available at 18:00, 20:00 and 21:00 UTC. Middle panels (b) show simulated CHRONOS observations using WRF-Chem (Grell et al., 2005) at $4 \mathrm{~km}$ horizontal resolution driven by analyzed meteorology (Barth et al., 2012) for the same date. Here blue colors indicate low $\mathrm{CO}(\sim 60 \mathrm{ppbv})$, red colors indicate high $\mathrm{CO}(\sim 300 \mathrm{ppbv})$ and light greys indicate clouds. Bottom panels (c) are a magnified view of the simulated CHRONOS observations. Circled areas provide examples of changes in CO concentrations over the $5 \mathrm{~h}$ period with pollution from Chicago moving to the west and clouds moving east over the Washington, D.C. area.

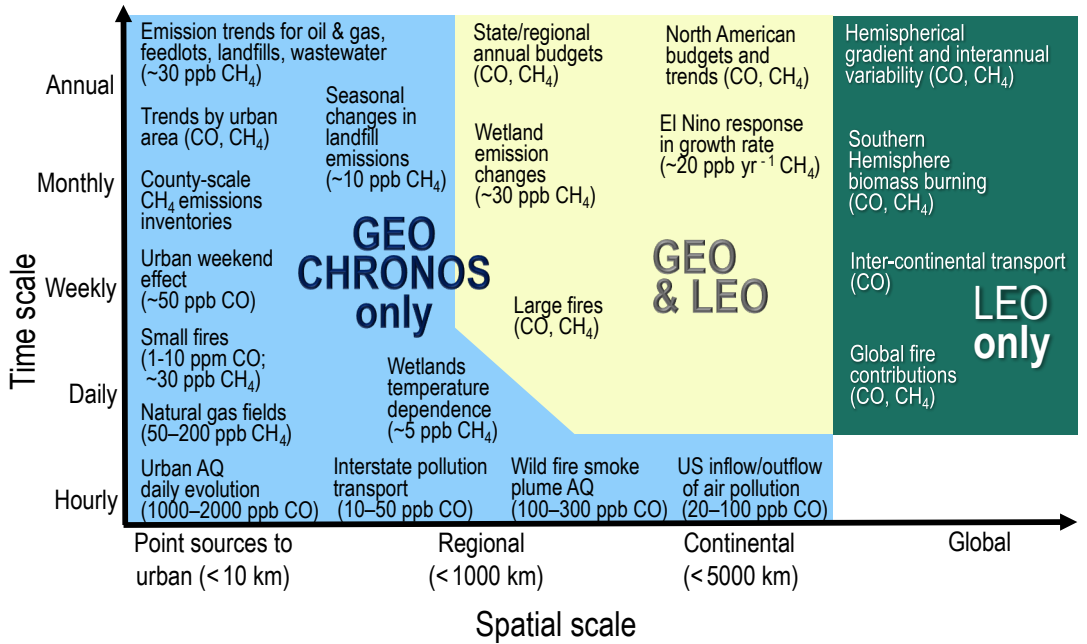

Figure 2. CHRONOS' sub-hourly observations would provide access to the fine temporal and fine spatial scales of $\mathrm{CH}_{4}$ and $\mathrm{CO}$ processes for understanding the emissions and transport of air pollution for air quality, climate and energy management applications. Estimated abundances are for process contributions above background levels.

the sources, transport and distributions of the gases important for air quality and climate (NRC, 2007; Simmons et al., 2016). LEO data provide valuable knowledge on continentalto global-scale pollution, but their spatial and temporal resolution, sparseness of coverage and often large uncertainties for individual trace gas observations have so far limited their use in understanding air pollution sources and distributions on local to regional spatial scales (Figs. 1 and 2).

The importance of sub-hourly time resolution for capturing the diurnal evolution of pollution transport is shown in Fig. 1, which compares current MOPITT measurement sampling to that which would be obtained from CHRONOS over the continental U.S.
Understanding the rapidly changing tropospheric state and critical processes that are episodic or have diurnal timescales - such as traffic emissions, forest fire intensity, meteorology and changes in the planetary boundary layer (PBL) height - requires temporal resolution that is better than once a day (Fishman et al., 2012). Accurate prediction of air quality requires an observing framework for atmospheric composition similar to that for weather forecasting, where instruments in GEO are essential components of the integrated observing system and complement existing LEO, suborbital and surface assets and modeling capability. As such, CHRONOS in GEO addresses the need for sub-hourly vertical and horizontal transport information for "chemical weather" prediction. 


\subsection{The CHRONOS science objectives}

CHRONOS focuses on two interrelated science objectives: emissions of highly variable and poorly quantified air pollutants, and air pollution transport across North America. Significant scientific advances in understanding these air pollutant emissions and transport processes are expected to lead to improvements in chemical transport model predictability on both regional and global scales.

Objective 1-emissions: quantify the temporal and spatial variations of $\mathrm{CH}_{4}$ and $\mathrm{CO}$ emissions for air quality, climate and energy decision making.

Large uncertainties and conflicting estimates exist in current $\mathrm{CO}$ and $\mathrm{CH}_{4}$ emissions. Aircraft data show National Emissions Inventory (NEI) CO emissions are too high by a factor of 3 in the summer (Hudman et al., 2008; Miller et al., 2008). Satellite data, including MOPITT, indicate large seasonal changes in $\mathrm{CO}$ emissions with a maximum in winter and minimum in summer (Kopacz et al., 2010), which are currently absent from the NEI, and show fire emissions that are too low by as much as $30 \%$ (Pechony et al., 2013). Measurements of $\mathrm{CH}_{4}$ from surface and aircraft observations imply that the EPA 2009 emission inventory is too low, by about a factor of 2 , due to large uncertainties from fossil fuel production (coal and natural gas fields, especially in the western United States and Canadian tar sands), transportation, agriculture, wetlands and thawing permafrost in Canada (Katzenstein et al., 2003; Xiao et al., 2008; Kort et al., 2008; Pétron et al., 2012; Miller et al., 2013; Pechony et al., 2013; Schwietzke et al., 2016). In particular, for natural gas production, recent studies present conflicting results. Karion et al. (2013) showed between 6 and $12 \% \mathrm{CH}_{4}$ leakage from gas and oil production fields in Unitah County, Utah, using airborne measurements, while Allen et al. (2013) found less than $1 \%$ leakage at 190 U.S. natural gas sites using emissions activity estimates. Recent research has identified sensor issues in the surface measurements used by natural gas companies often causing under-estimated emissions (Howard et al., 2015). These observational inconsistencies can be resolved by comprehensive measurements that are temporally and spatially dense.

CO observations also serve as a proxy for other pollutant emissions. Emissions of other combustion pollutants that are important to air quality and climate are frequently correlated with $\mathrm{CO}$ emissions, including other ozone and aerosol precursors (Edwards et al., 2004; Massie et al., 2006; Zhang et al., 2006; Bian et al., 2010). As a result, the emission inputs to chemical transport models for many combustion-related species are specified by ratios referenced to $\mathrm{CO}$. $\mathrm{CO}$ serves as a proxy for anthropogenic carbon dioxide $\left(\mathrm{CO}_{2}\right)$ (Palmer et al., 2006; Worden et al., 2012; Silva et al., 2013) and black carbon (BC) sources (Arellano et al., 2010). $\mathrm{CH}_{4}$ correlations with $\mathrm{CO}$ distinguish $\mathrm{CH}_{4}$ from fires (J. Worden et al., 2013a). Assimilation of CHRONOS data into regional-scale chemical transport models would leverage inter-species constraints to allow the emissions and distributions of correlated species to be inferred using CHRONOS measurements (e.g., Gaubert et al., 2016).

Objective 2 -transport: track rapidly changing vertical and horizontal atmospheric pollution transport to determine near-surface air quality at urban to continental spatial scales, and at diurnal to monthly temporal scales.

Source attribution for local and transported pollution is an important step toward attaining air quality standards (NRC, 2004). Understanding the production of air pollution requires knowledge of ozone and aerosol precursor emissions (CO and $\mathrm{CH}_{4}$ among them), and the transport of both precursors and other air quality pollutants (for example, using $\mathrm{CO}$ as a tracer). Air pollution crosses international and state boundaries to impact downwind cities, national parks and wilderness areas. The Cross-State Air Pollution Rule (U.S. EPA, 2011) requires 27 states to reduce emissions in order to meet air quality standards in downwind states. Considerable international efforts are directed toward understanding intercontinental transport of air pollution (Galmarini et al., 2017). CHRONOS' multispectral retrievals of $\mathrm{CO}$ would provide the vertical sensitivity to determine transport out of the PBL and into the free troposphere, and the vertical descent back to the surface at some distance downwind. This new CHRONOS information would allow state and local air quality managers to quantify interstate pollution, along with intermittent sources such as fires that affect the ability of urban areas to meet air quality standards.

The temporal and spatial scales of CHRONOS measurements are designed to be similar to the scales of models for regional air quality applications, leading to improvements in process representation. From observing system simulation experiments (OSSEs), we have demonstrated that data assimilation of simulated CHRONOS multispectral observations of CO significantly improves comparisons with the "true" surface CO values at EPA surface monitoring sites (Edwards et al., 2009). Sub-hourly measurements of CO throughout the troposphere would allow for more frequent data assimilation updates than is currently possible, which, along with increased accuracy in surface CO knowledge, would dramatically improve the skill for air quality prediction. OSSEs also demonstrate that CHRONOS' CO measurements augment TEMPO's ozone measurement capability through joint ozone-CO data assimilation (Zoogman et al., 2014).

\subsection{CHRONOS measurements of $\mathrm{CH}_{4}$ and $\mathrm{CO}$}

More than half of $\mathrm{CH}_{4}$ emissions are anthropogenic, with contributions from fossil fuel production, animal husbandry and waste management, while wetlands are the primary natural source (Bergamaschi et al., 2009). $\mathrm{CH}_{4}$ has an atmospheric lifetime of $8-10$ years and exerts 86 times the global warming potential of $\mathrm{CO}_{2}$ emissions on a 20 -year time frame (Myhre et al., 2013). The U.S. is presently the world's largest producer of natural gas (Breul and Doman, 2013). Produc- 
tion has increased $20 \%$ since 2008 , with a corresponding need to quantify how much $\mathrm{CH}_{4}$ is released during extraction. Furthermore, $\mathrm{CH}_{4}$ has an impact on air quality as a precursor to tropospheric ozone and aerosols through changes in the hydroxyl radical $(\mathrm{OH})$ (Shindell et al., 2009). $\mathrm{CH}_{4}$ thus plays a pivotal role in both air quality and climate, and cobenefits to both air quality and climate may arise from reducing $\mathrm{CH}_{4}$ emissions (West et al., 2006; Shindell et al., 2009; UNEP, 2011; Schneising et al., 2014). CHRONOS' frequent (sub-hourly) $\mathrm{CH}_{4}$ observations would provide the information needed to resolve discrepancies in $\mathrm{CH}_{4}$ emissions at the county, decision-making, scale.

Dense data sampling improves the capability for constraining model emissions (e.g., Bousserez et al., 2016; Wecht et al., 2014a). Figure 3 shows a grid representing the CHRONOS spatial resolution overlaid on aircraft measurements taken during the FRAPPE-DISCOVER-AQ field campaign (Pfister et al., 2017) in the Colorado Front Range on 2 August 2014. This indicates high $\mathrm{CH}_{4}$ in areas of extensive oil and gas extraction and feedlot operations in Colorado (Greeley and Platteville), as compared to other urban and rural locations. By comparison, $\mathrm{CH}_{4}$ concentrations during the 2015 Aliso Canyon leak (Conley et al., 2016) over the Los Angeles Basin were an order of magnitude higher than these Colorado oil and gas concentrations and thus could have been quantified from space using CHRONOS $\mathrm{CH}_{4}$ observations, had they been available. Recent studies have demonstrated the potential for using $\mathrm{CO}$ and $\mathrm{CH}_{4}$ satellite data to constrain sources using adjoint and other inversion models (Bergamaschi et al., 2007, 2009; Meirink et al., 2008; Kopacz et al., 2009, 2010; Fortems-Cheiney et al., 2011; Pechony et al., 2013; Wecht et al., 2014b; A. J. Turner et al., 2015; Jacob et al., 2016). These studies also show that present ability to optimize emission estimates is limited by the sparse sampling of present measurements. CHRONOS would provide the data density and near-surface abundance information that is needed in adjoint inversions for $\mathrm{CO}$ and $\mathrm{CH}_{4}$ emissions estimates with the spatial and temporal resolution necessary to understand emission inventory errors.

Nine months before the U.S. Environmental Protection Agency was founded, air quality criteria were established for CO (U.S. Department of Health, Education, and Welfare, Public Health Service, National Air Pollution Control Administration, 1970) to protect public health in compliance with the 1967 amendments (Public Law 90-148) to the Clean Air Act of 1963 (Public Law 88-206). CO is produced by combustion processes - including transportation, manufacturing, agricultural burning and wildfires - and by hydrocarbon oxidation. $\mathrm{CO}$ participates in the formation of ground level ozone; as the dominant sink for the main tropospheric oxidant, $\mathrm{OH}, \mathrm{CO}$ plays a central role in determining the ability of the atmosphere to cleanse itself of pollutants (e.g., Holloway et al., 2000) and thus affects the lifetime of $\mathrm{CH}_{4}$ (Myhre et al., 2013). The CO lifetime of $\sim 2$ months provides time for $\mathrm{CO}$ to be transported globally, yet is suffi-

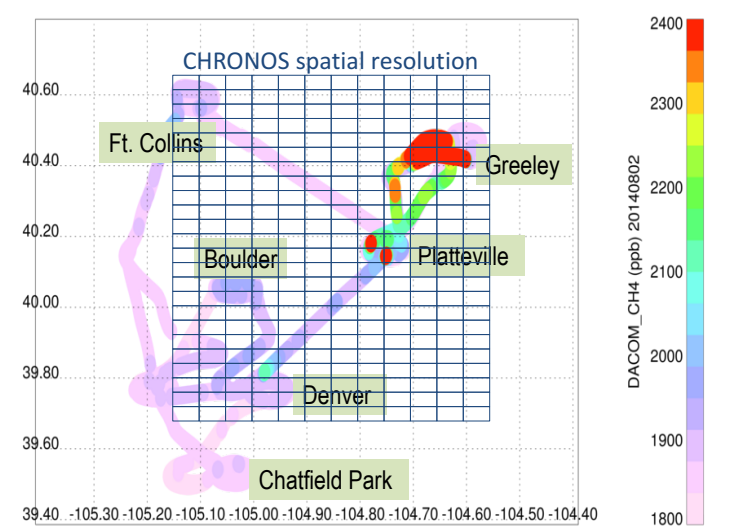

Figure 3. Aircraft in situ measurements of $\mathrm{CH}_{4}$ from the FRAPPEDISCOVER-AQ in the Colorado Front Range on 2 August 2014. Vertical profiles were measured over cities, identified by spiral flight tracks (each spiral has $\sim 10 \mathrm{~km}$ radius), where the highest values of $\mathrm{CH}_{4}$ are plotted last. Total column $\mathrm{CH}_{4}$ computed from the vertical profiles is different by $4.9 \%$ between Greeley (oil/gas and feedlot operations) and Ft. Collins (urban). CHRONOS pixel spatial resolution is indicated by the overlaid grid, illustrating that CHRONOS column measurements would have the spatial resolution and precision to distinguish sub-hourly differences in county-scale $\mathrm{CH}_{4}$ abundances. Note that the grid in this figure only indicates pixel resolution and not the observational domain; CHRONOS images the entire North American field of view in each $60 \mathrm{~ms}$ frame. DA$\mathrm{COM}$ (differential absorption carbon monoxide monitor) $\mathrm{CH}_{4}$ data are courtesy of Glenn Diskin, NASA.

ciently short to show large contrasts between polluted air and the background atmosphere (Edwards et al., 2004). For these reasons, $\mathrm{CO}$ is one of the few mission-critical measurements in all aircraft campaigns of the NASA Global Tropospheric Chemistry Program (Fisher et al., 2010) and similar regional air pollution studies. CHRONOS would use the CO multispectral retrieval created by the MOPITT team providing enhanced sensitivity to near-surface $\mathrm{CO}$ concentrations (Worden et al., 2010; Deeter et al., 2013). This allows CO plumes near the surface to be distinguished from plumes in the free troposphere to quantify how sources of CO impact downwind regions (Huang et al., 2013). This approach is discussed in Sect. 5.

\section{The gas correlation filter radiometry (GCFR) measurement technique}

\subsection{GCFR concepts}

Gas filter correlation radiometry features extremely high spectral selectivity combined with high throughput to enable precise measurements of atmospheric trace constituents such as $\mathrm{CH}_{4}$ and CO. GCFR (Acton et al., 1973; Ludwig et al., 1972; Tolton and Drummond, 1997) has been used for satellite remote sensing on Space Shuttle/MAPS (Reichle et al., 
1999), UARS/ISAMS and HALOE (Rodgers et al., 1996; Russell et al., 1993), and Terra/MOPITT (Edwards et al., 1999; Drummond et al., 2010). The pioneering MAPS instrument used two detectors with careful electronic balancing on its four Space Shuttle flights to measure CO, and MOPITT uses length and pressure modulation of a single cell, rather than separate gas and vacuum cells, for its successful observations during more than 17 years in LEO. Correlation radiometers have thus proven rugged and reliable in space. The first decadal survey for Earth Science and Applications from Space recommended "an IR correlation radiometer for $\mathrm{CO}$ mapping" and also stated that the "combination of the near-IR and thermal-IR data will describe vertical $\mathrm{CO}$, an excellent tracer of long-range transport of pollution" (NRC, 2007).

The GFCR technique is based on the concept that the nearideal filter for the spectral signal from a particular molecule comes from the molecule itself. The effective spectral resolution of the GFCR response function (Edwards et al., 1999, Fig. 3) matches the pressure-broadened Lorentz full width at half maximum (FWHM) for weak-absorption lines (Beer, 1992) and ranges from 0.08 to $0.16 \mathrm{~cm}^{-1}$ for 200 to $800 \mathrm{hPa}$ GFCR gas cells (Pan et al., 1995). This optimal spectral resolution for measuring tropospheric trace gas absorption and for probing the spectral line profile to obtain information on the trace gas atmospheric vertical distribution is difficult to achieve for most spectrometers without sacrificing signal amplitude (grating spectrometers) or increasing noise (Fourier transform spectrometers, FTSs). The limitation for the GFCR technique is that atmospheric retrievals are made only for those gases contained within the cells of the instrument. However, for observations of $\mathrm{CO}$ and $\mathrm{CH}_{4}$ from $\mathrm{GEO}$ (50 times farther from Earth than LEO), the advantages of both high effective spectral resolution and high throughput provided by CHRONOS' gas filter correlation radiometry make for a particularly robust measurement approach.

In the GFCR technique, shown schematically in Fig. 4, the top-of-atmosphere (TOA) spectral radiance from each observed field of view (FOV) passes through an instrument cell containing the same gas as the atmospheric target gas being measured, either $\mathrm{CO}$ or $\mathrm{CH}_{4}$ in the case of CHRONOS. The instrument cell uses the gas of interest as a highly selective filter to match narrow spectral features in the atmosphere. With known gas cell dimensions, gas content, temperature and pressure, this technique provides nearly perfect spectral knowledge. The GFCR method efficiently filters the target gas information from surrounding spectral interference, while simultaneously measuring and integrating the target spectra across the selected spectral band pass, delivering a spectral response function that can be accurately calibrated because it is defined by the cell gas absorption. For these reasons, thorough GFCR instrument characterization is needed prior to launch, along with on-orbit radiometric calibration and measurements of cell parameters (Neil et al., 2001).

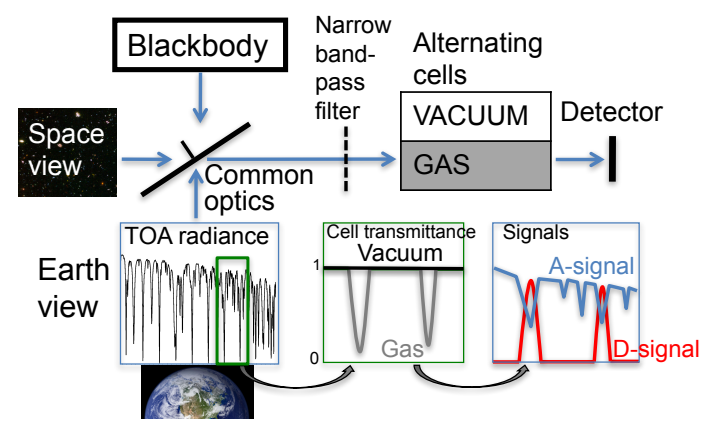

Figure 4. Simplified depiction of the CHRONOS GFCR measurements to show how average $(A)$ and difference $(D)$ signals are generated from spectrally correlated, band-integrated radiance measurements through the vacuum $(V)$ and gas $(G)$ cells. Upwelling atmospheric radiance passes through a narrow band-pass filter, selected for the target gas spectral range; through a target gas cell; and on to a detector pixel. For CHRONOS, within $60 \mathrm{~ms}$, the atmospheric radiance passes through an identical band-pass filter, an identical reference vacuum cell, and falls on the same detector pixel.

Idealized implementation of gas filter correlation radiometry requires viewing the same scene through the same optics with the same detector for each of two gas cells (one containing the gas of interest and the other containing a vacuum or a gas with no spectral signature in the selected spectral region). The goal is that the ratio of the spectral radiance viewed through the two cells is only a function of the target gas. Spatial misalignment of the two measurements could result in changes in the viewed surface reflectivity, and thus radiance changes in gas-vacuum cell difference. Temporal offsets could result in different atmospheric paths being captured because of target gas or cloud movement through the field of view. Changes in the instrument function between gas and vacuum views (different optics or detector) are equivalent to radiance errors. The CHRONOS implementation provides nearly simultaneous acquisition of the gas and vacuum cell signals through a common optical path and minimizes ground co-registration errors between signal pairs. Observation simulation studies using representative GEO spacecraft pointing data have been performed to determine the effect of "jitter" in spacecraft pointing during the acquisition of a signal pair. The displacement between a single paired gasvacuum measurement is limited to $\leq 5 \mu \mathrm{rad}$ to ensure acceptable changes in ground pixel reflectance based on $\mathrm{MO}$ PITT experience (Deeter et al., 2011). This requirement corresponds with a gas cell-to-vacuum cell frame time limited to $60 \mathrm{~ms}$, readily achievable with a physically realistic cell size and rotation frequency, frame acquisition and readout rate. The large $(>3000 \mathrm{~kg}$ ) size of a commercial communications spacecraft therefore serves to naturally attenuate jitter sources over very short time frames, avoiding the need for a costly image stabilization subsystem.

In gas filter correlation radiometry, the relationship of the instrument analog signal and the actual spectrum must be in- 

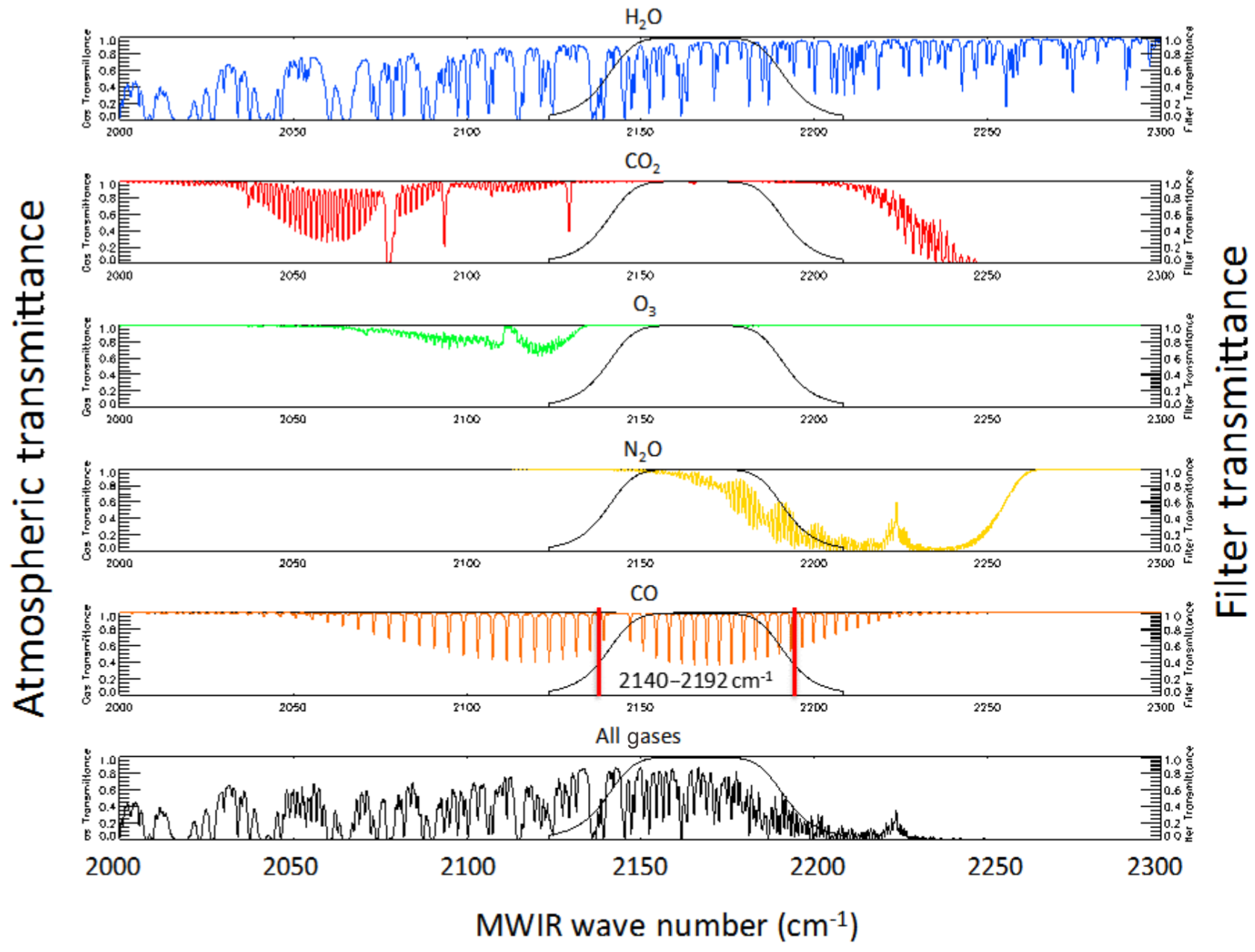

Figure 5. Atmospheric transmittance for primary trace gases in the MWIR vs. wave number. The CHRONOS filter transmission is indicated by smooth band-pass curves with solid red lines at filter half-power points (50\% transmittance). CHRONOS measures only CO in the MWIR.

terpreted using a forward atmospheric model and line-by-line spectral radiative transfer calculations (Pan et al., 1995). For instrument development, these calculations form the basis of the instrument spectral-characteristics definition (band pass and width for each target gas and spectral region) and quantify the instrument sensitivity to the target gas; the effects of signatures of non-target gases in the selected spectral region; and the effects of variations in the underlying surface temperature, emission and reflectivity. After launch, these calculations are a crucial part of the instrument model used in data retrieval.

\subsection{Spectroscopy of $\mathrm{CO}$ and $\mathrm{CH}_{4}$ and the CHRONOS instrument signals}

Two CO spectral bands, the midwave infrared (MWIR) fundamental at $4.6 \mu \mathrm{m}$ (Fig. 5) and the shortwave infrared (SWIR) overtone band at $2.3 \mu \mathrm{m}$ (Fig. 6), are the only spectral regions that produce $\mathrm{CO}$ features easily distinguished from the surrounding spectra at wavelengths shorter than mi- crowave and thus are useful for passive remote sensing of tropospheric CO (e.g., Edwards et al., 1999, 2009). Measurements in the MWIR band rely on thermal emission from the Earth's surface and atmosphere (that can be obtained both day and night), and relatively strong spectral features. Measurements in the MWIR are only sensitive to changes in lower-atmosphere $\mathrm{CO}$ concentration when sufficient thermal contrast exists between the surface and near-surface atmosphere (Deeter et al., 2004). Typically, MWIR signals are most sensitive to $\mathrm{CO}$ concentration changes in the midtroposphere, where long-range pollution transport typically occurs. In contrast, measurements in the CO SWIR band rely on solar radiation reflected from the Earth's surface in daylight, with comparatively weak CO spectral features (Deeter et al., 2009). Typically, the SWIR signal has almost uniform sensitivity to changes in the $\mathrm{CO}$ vertical profile, including information near the surface.

Several spectral bands may be considered for retrieving $\mathrm{CH}_{4}$. Infrared measurements near $7.7 \mu \mathrm{m}$ (e.g., Payne et al., 

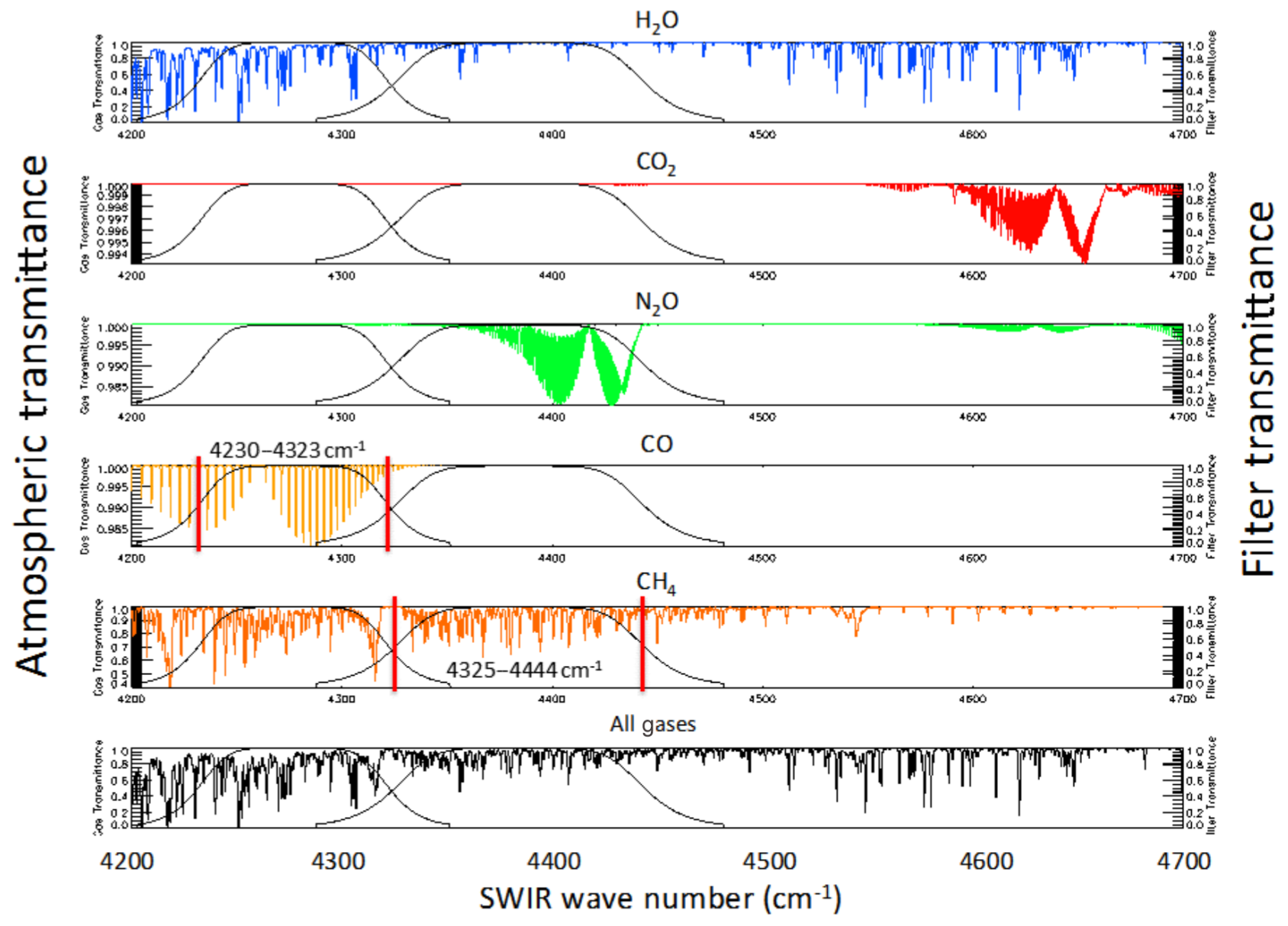

Figure 6. Atmospheric transmittance for primary trace gases in the SWIR vs. wave number. CHRONOS filter transmission is indicated by

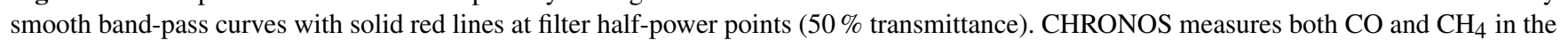
SWIR.

2009) generally lack sensitivity to near-surface $\mathrm{CH}_{4}$, similar to MWIR CO. Both SCIAMACHY (e.g., Frankenberg et al., 2005, 2011; Wecht et al., 2014b) and GOSAT (e.g., Morino et al., 2011; Schepers et al., 2012) have produced $\mathrm{CH}_{4}$ data products using reflected sunlight in the SWIR to obtain a true total column. CHRONOS will also measure a $2.2 \mu \mathrm{m}$ SWIR $\mathrm{CH}_{4}$ band, shown in Fig. 6.

The GFCR instrument generates spectrally correlated, band-integrated radiance measurements through alternate gas and vacuum cells, producing radiance pairs. As shown in Fig. 4, the difference ( $D$ signal), constructed by differencing the gas and vacuum cell radiances, contains spectral contributions only from the target gas absorption line positions within the spectral passband. The average ( $A$ signal), the mean of the gas and vacuum cell radiances, has a spectral contribution that is low at the target gas line positions and high elsewhere. As such, the $A$ signal carries background information on the FOV scene characteristics. Therefore, the ratio of the $D$ signal to $A$ signal, $D / A$, eliminates the background radiance term and reduces the impact of uncertainties associated with surface reflectance, interfering gases, or optically thin aerosols and clouds. In non-optically thin cases of clouds or aerosols $(\mathrm{OD} \gtrsim 0.2$, identified using the Geostationary Operational Environmental Satellite Advanced Baseline Imager, or GEOS ABI, cloud mask, for example), data are discarded, and no retrieval is performed. This approach is possible due to the high temporal and spatial sampling of CHRONOS and the availability of ancillary cloud and aerosol geostationary observations, both current and expected (e.g., Heidinger, 2011).

The designated pressure in the instrument cell determines the width of the fill-gas spectral lines and thus the effective spectral sampling resolution of the correlation filter. We note that the CHRONOS MWIR CO and SWIR $\mathrm{CH}_{4}$ bands also contain water vapor $\left(\mathrm{H}_{2} \mathrm{O}\right)$ and nitrous oxide $\left(\mathrm{N}_{2} \mathrm{O}\right)$ absorption features (Figs. 5 and 6). The gas correlation removes the absorption effects of these interfering gases for the $D$ signal. The interference of $\mathrm{H}_{2} \mathrm{O}$ and $\mathrm{N}_{2} \mathrm{O}$ in both the MWIR and SWIR channel $A$ signals is modeled in the forward-model radiative transfer algorithm using analyzed $\mathrm{H}_{2} \mathrm{O}$ concentra- 
tion fields from meteorological data and inferred $\mathrm{N}_{2} \mathrm{O} . \mathrm{N}_{2} \mathrm{O}$ is a long-lived gas $(\sim 120$ years $)$ with predictable variability (Angelbratt et al., 2011).

SCIAMACHY and GOSAT $\mathrm{CH}_{4}$ SWIR retrievals are sensitive to scattering by dust, aerosols and thin cirrus (Gloudemans et al., 2008; Schepers et al., 2012) and address these errors by using $\mathrm{CO}_{2}$ (with known abundance) as a proxy for the scattering effects or by performing a physical retrieval of effective parameters for the scattering layer. For GOSAT $\mathrm{CH}_{4}$ data, these two approaches yield similar precision $(\sim 17 \mathrm{ppb})$ and biases less than $1 \%$ compared to the Total Carbon Column Observing Network (TCCON; Wunch et al., 2010), but with lower bias for the proxy method (Schepers et al., 2012). In the proxy retrieval using $\mathrm{CO}_{2}$, the dry mole fraction of $\mathrm{CH}_{4}(\mathrm{XCH} 4)$ is computed by $\mathrm{XCH} 4=\frac{\left[\mathrm{CH}_{4}\right]}{\left[\mathrm{CO}_{2}\right]} \mathrm{XCO} 2$, where $\left[\mathrm{CH}_{4}\right]$ and $\left[\mathrm{CO}_{2}\right]$ are the retrieved columns from spectral radiances that are close in wave number and XCO2 is the dry mole fraction computed from a global model of atmospheric $\mathrm{CO}_{2}$ (Frankenberg et al., 2005; Schepers et al., 2012). This method assumes that aerosol scattering modifies the light path for $\mathrm{CO}_{2}$ and $\mathrm{CH}_{4}$ spectral absorption in the same way, and that model values for $\mathrm{XCO} 2$ are accurate.

Retrievals with GFCR measurements are similar to the "proxy retrieval", but they correct the input radiance instead of the retrieved column, and do not make assumptions about aerosol scattering in different spectral bands or rely on knowing $\mathrm{CO}_{2}$ abundance. CHRONOS uses the $D / A$ signal ratio, where $D$ and $A$ are both modified in the same way by aerosol scattering, which has a smooth spectral behavior over the CHRONOS band pass. For optically thin aerosol and cloud scenes, this ratio gives an accurate total column amount, but to compute a dry mole fraction ( $\mathrm{XCH} 4)$, we require additional information about the surface pressure (for example, from GOES-16 meteorological data) in order to estimate the dry air column. In general, GFCR retrievals are more resilient than spectral radiance measurements to errors in surface and contaminant species assumptions due to the use of radiance differences and ratios (Pan et al., 1995).

\subsection{Measurement radiometric accuracy and precision}

By using $D / A$ signal ratios, the GFCR technique is inherently less sensitive to radiance bias errors than spectrometer measurements. However, three primary sources of potential retrieval bias remain: surface albedo spectral variability; aerosol scattering; and water vapor errors in meteorological data, which are typically $<10 \%$ for North America (Vey et al., 2010). Spectral variation in surface albedo proved to be a significant obstacle for MOPITT $\mathrm{CH}_{4}$ retrievals (Pfister et al., 2005). This was because of the width and spectral location of the MOPITT passband, combined with changingscene albedo arising from LEO spacecraft motion during the acquisition of a single measurement (Deeter et al., 2011). For CHRONOS, the $\mathrm{CH}_{4}$ passband has been optimized in both width and spectral location (Table 1) to mitigate these errors.
For a GFCR, the radiance precision needed to measure a change in column is given by $\Delta D / A$, for $D$ and $A$ defined above, where $\Delta D$ is determined using the instrument sensitivity to the column change $(\partial D / \partial$ col) (Pan et al., 1995). Profile or column retrieval precision requirements are achieved in ground processing by averaging geolocated, cloud-screened radiances for $3 \mathrm{~min}$ (375 separate gas-vacuum measurements for $\mathrm{CO}(4.6 \mu \mathrm{m}, 800 \mathrm{hPa}), \mathrm{CO}$ $(4.6 \mu \mathrm{m}, 200 \mathrm{hPa})$ and $\mathrm{CO}(2.3 \mu \mathrm{m}, 100 \mathrm{hPa})$, and $750 \mathrm{mea}-$ surements of $\left.\mathrm{CH}_{4}(2.2 \mu \mathrm{m}, 800 \mathrm{hPa})\right)$. A single retrieval for each product is performed on these averaged radiances. The process of averaging radiances and then retrieving products is repeated for all data acquired in the $9.7 \mathrm{~min}$ data acquisition period. Table 1 lists the modeled signal-to-noise ratio (SNR) and the total number of individual data acquisitions in each pixel in the 2-D detector array ("frames") obtained in a single $9.7 \mathrm{~min}$ data acquisition period, for the minimum radiance case defined from MOPITT on-orbit radiance records. This minimum SNR provides at least a $30 \%$ margin for meeting the radiance precision requirements.

$\mathrm{CO}$ profile retrievals require $10 \%$ precision to capture the fine-scale space and time variability of $\mathrm{CO}$ and quantify transient sources (Fishman et al., 2012; Emmons et al., 2009). Based on GEO-CAPE $\mathrm{CH}_{4}$ emission OSSEs (Wecht et al., 2014a), monthly emissions estimates with $<10 \%$ error on county-level spatial scales $(\sim 40 \mathrm{~km} \times 40 \mathrm{~km})$ require a daily precision on averaged retrievals of total column $\mathrm{CH}_{4}<1 \%$. CHRONOS will deploy two identical $\mathrm{CH}_{4}$ channels with combined $0.7 \%$ precision for a $9.7 \mathrm{~min}$ data acquisition that exceeds the GEO-CAPE daily requirement. The CHRONOS sub-hourly $\mathrm{CH}_{4}$ sampling capability and the relatively slow rate of change in $\mathrm{CH}_{4}$ column abundance enable the combining of samples to further improve $\mathrm{CH}_{4}$ column precision, allowing identification of $\mathrm{CH}_{4}$ changes on daily scales, and verification of state and federal pollution reduction goals (Miller et al., 2013). As discussed in Sect. 3.2, a major advantage of the GFCR measurement technique is the ability to eliminate any contaminating signal that is not spectrally correlated with the lines of the cell target gas. In the spectral regions utilized by CHRONOS, water vapor spectral lines are ubiquitous; in the SWIR, the effects of aerosol must be considered. Figure 7 shows CHRONOS-simulated $A$ and $D$ signals for midlatitude summer atmospheric conditions (Anderson et al., 1986), with and without aerosol scattering. The VLIDORT radiative transfer model (Spurr, 2006) is used for modeling the aerosol scattering, and the OPAC (Optical Properties of Aerosols and Clouds) database (Hess et al., 1998) provides AOD adjusted to $2.25 \mu \mathrm{m}$. The case shown in Fig. 7 is for AOD that is 50\% larger than the OPAC urban aerosol case. Based on the simulated retrievals we perform, $1 \%$ errors in total column correspond to $0.2 \%$ errors in $D / A$. The nominal urban aerosol loading considered in OPAC would lead to $\sim 0.026 \%$ errors in $D / A$, which translates to a $\sim 0.13 \%$ error in total column. Similar errors in $D / A$ due to aerosol scattering are obtained for the 
Table 1. The multi-layer dielectric optical coatings on the CHRONOS gas cell windows define the center wavelength and band pass. Each spectral coating and cell pressure is identified through modeling to provide the optimal measurement. The signal-to-noise ratio (SNR) listed provides at least a $30 \%$ margin over the SNR required to achieve radiance precision. All data frames are obtained within a single 9.7 min data acquisition period.

\begin{tabular}{llrrrrrr}
\hline Cell & Gas filter & $\begin{array}{r}\text { Center } \lambda \\
(\mu \mathrm{m})\end{array}$ & $\begin{array}{r}\text { Cell pressure } \\
(\mathrm{hPa})\end{array}$ & $\begin{array}{r}\text { Band pass } \\
(\mu \mathrm{m})\end{array}$ & $\begin{array}{r}\text { Band pass } \\
\left(\mathrm{cm}^{-1}\right)\end{array}$ & $\begin{array}{r}\text { Co-added SNR at } \\
\text { minimum radiance }\end{array}$ & $\begin{array}{r}\text { Number of } \\
\text { frames obtained }\end{array}$ \\
\hline 1 & $\mathrm{CO}$ & 4.6 & 200 & $4.562-4.673$ & $2140-2192$ & 595 & - \\
2 & Vacuum & 4.6 & 0 & $4.562-4.673$ & $2140-2192$ & 55 \\
3 & $\mathrm{CO}$ & 4.6 & 800 & $4.562-4.673$ & $2140-2192$ & 355 & 95 \\
\hline 4 & $\mathrm{CO}$ & 2.3 & 100 & $2.313-2.364$ & $4230-4323$ & - & 889 \\
5 & Vacuum & 2.3 & 0 & $2.313-2.364$ & $4230-4323$ & 4390 & - \\
\hline 6 & $\mathrm{CH}_{4}$ & 2.2 & 800 & $2.250-2.312$ & $4325-4444$ & - & 1012 \\
7 & Vacuum & 2.2 & 0 & $2.250-2.312$ & $4325-4444$ & 4390 & 1012 \\
8 & $\mathrm{CH}_{4}$ & 2.2 & 800 & $2.250-2.312$ & $4325-4444$ & & - \\
\hline
\end{tabular}

Table 2. Expected precision and accuracy for CHRONOS.

\begin{tabular}{|c|c|c|c|}
\hline Column error source & MWIR CO (night) & $\begin{array}{r}\text { MWIR + SWIR } \\
\text { CO (day) }\end{array}$ & $\begin{array}{r}\mathrm{SWIR}^{\mathrm{CH}_{4}} \\
\text { (day) }\end{array}$ \\
\hline Precision requirement & $<10 \%$ & $<10 \%$ & $<0.7 \%$ \\
\hline MOPITT performance & $5-15 \%$ & $2-10 \%$ & $\mathrm{n} / \mathrm{a}$ \\
\hline Corresponding SNR $(A / \Delta D)$ & 457 & 2499 & 3374 \\
\hline Radiometric bias & $<0.1 \%$ & $<0.1 \%$ & $<0.1 \%$ \\
\hline $10 \%$ water vapor error & $<0.7 \%$ & $<0.7 \%$ & $<0.15 \%$ \\
\hline Albedo variation & $\begin{array}{r}\text { Negligible for MWIR } \\
\text { CO band }\end{array}$ & $<0.06 \%$ & $<0.1 \%$ \\
\hline Urban aerosol loading & Negligible in MWIR ${ }^{b}$ & $<0.03 \%$ & $<0.13 \%$ \\
\hline
\end{tabular}

CHRONOS $2.3 \mu \mathrm{m}$ CO channel and can then be compared to MOPITT measurement errors in $D / A$ that are around 1 to $2 \%$ for scenes with minimal geophysical noise. The insensitivity of $D / A$ to aerosol scattering is found to hold for a large range of aerosol types and loading, with the largest errors (up to $0.3 \%$ ) due to desert dust, consistent with Gloudemans et al. (2008). Expected errors due to uncertainties in water vapor were also simulated using perturbations of the midlatitude summer atmosphere and are $<1 \%$ for $\mathrm{CO}$ and $<0.2 \%$ for $\mathrm{CH}_{4}$.

A summary of CHRONOS precision and accuracy requirements for column $\mathrm{CO}$ and $\mathrm{CH}_{4}$ is given in Table 2. Validation activities for CHRONOS will use aircraft profiles from ongoing flight programs, such as IAGOS (Nédélec et al., 2015) and existing ground data networks such as TCCON (Wunch et al., 2010) to detect biases in $\mathrm{CO}$ and $\mathrm{CH}_{4}$ similar to the proven approach used for GOSAT and OCO-2 validation (Schepers et al., 2012).

\section{The CHRONOS instrument and operation}

The CHRONOS measurement domain, shown in Fig. 8, extends over North America and includes adjacent oceans in order to observe pollution inflow and outflow using observations in the MWIR CO channels. In the SWIR channels, sunlight is mostly absorbed in the ocean, and no trace gas retrievals are expected over the ocean in the SWIR channels. The CHRONOS ground sample area varies gradually across the field of view due to curvature of the Earth as seen from GEO, with smaller than $4 \mathrm{~km} \times 4 \mathrm{~km}\left(16 \mathrm{~km}^{2}\right)$ nominal pixel area at the center of the domain, increasing to $19.3 \mathrm{~km}^{2}$ at the edge of the contiguous United States (CONUS) domain (e.g., Seattle). This spatial resolution enables emissions estimates at the U.S. county scale even for the smallest county in the continental U.S., New York County (i.e., Manhattan), NY, which contains 3.5 CHRONOS pixels. The increase in pixel size toward northern latitudes is commensurate with the increasing scale of dominant emissions sources, such as largescale wetlands in Canada (e.g., Pickett-Heaps et al., 2011). 
TOA "D" radiance with aerosol (blue), without aerosol (black): OPAC urban x 1.5

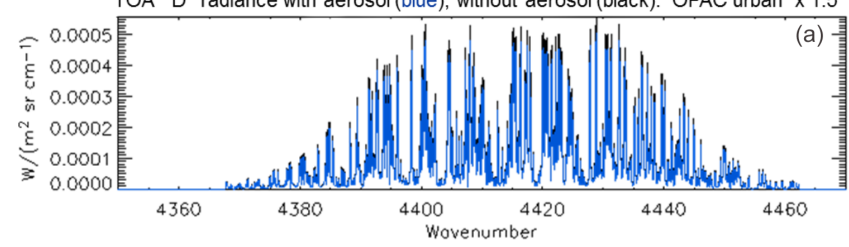

TOA "A" radiance with aerosol (blue), without aerosol (black): OPAC urban $\times 1.5$

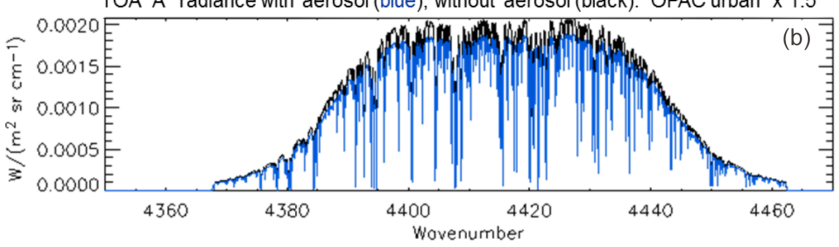

Figure 7. Forward-model results with aerosol loading. Simulated radiance spectra for CHRONOS corresponding to TOA $D$ (a) and $A$ (b) signals with the CHRONOS $\mathrm{CH}_{4}$ SWIR channel band pass applied. Simulations are for a midlatitude summer atmosphere with solar zenith angle $=0$, satellite zenith angle $=40^{\circ}$ and surface albedo $=0.2$. Black lines represent the case without aerosol scattering, and blue lines show radiances with aerosol scattering for urban aerosols (AOD is 0.089 , which is obtained by scaling the OPAC urban aerosol case by 1.5). $D / A$ is computed after integration over the band pass and is changed by $-0.039 \%$ for the case with aerosols compared to without.

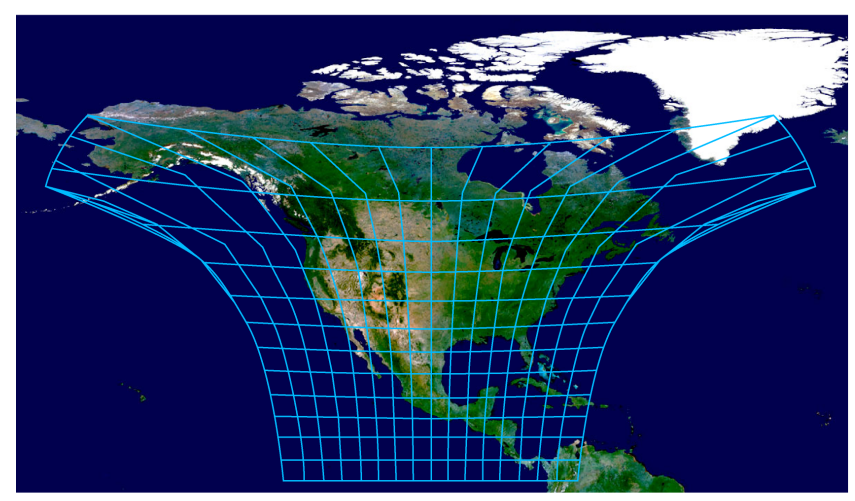

Figure 8. CHRONOS field of view from geostationary orbit at $100^{\circ} \mathrm{W}$. Each grid cell above represents $125 \times 125$ pixels. All pixels are acquired with full precision within the $\sim 10 \mathrm{~min}$ CHRONOS data acquisition.

To account for these variations, CHRONOS Level 2 (individual retrieval) data will be re-gridded (Vijayaraghavan et al., 2008; Guizar-Sicairos et al., 2008) in Level 3 (gridded) data to facilitate user scientific analysis using standard tools.

The CHRONOS GFCR is a staring infrared 2-D camera with a continuously rotating wheel that houses gas and vacuum cells, which sequentially pass through the optical path. Figure 9 depicts the instrument, which comprises optomechanical, calibration, focal plane, thermal and control electronics subsystems. Within the optomechanical subsystem, the gas cell filter wheel assembly contains cells as specified in Table 1. A selection mirror determines the source of the input radiance being filtered by the cells and imaged by the optics (Earth view, onboard calibration subsystem, a deep space view, and a blocked or closed position).

CHRONOS uses an all-digital (Brown et al., 2010) cryogenically cooled $\mathrm{HgCdTe}$ large-area focal plane array to detect the spectral radiance. The CHRONOS instrument has been designed around commercially available, spaceproven, radiation-hardened large-format focal plane arrays (e.g., flown on India's Chandrayaan-1 mission/NASA Moon Mineralogy Mapper, Green et al., 2011; DOD's CHIRP experiment, Levi et al., 2011; and NASA's Near Infrared Camera on the James Webb Space Telescope, Garnett et al., 2004). Low dark current $\left(6.2 \times 10^{9}\right.$ electrons $\mathrm{cm}^{-2} \mathrm{~s}^{-1}$ at $110 \mathrm{~K}$ ); low readout noise (high gain: 40 electrons rms; low gain: 200 electrons rms), high, stable quantum efficiency ( 0.7 at 2.2, 2.3, and $4.6 \mu \mathrm{m}$ ); and fast electronics are necessary characteristics for this application. For a 2-D imager such as CHRONOS, the pixel format (presently $2048 \times 2048$ ) and the desired observational domain determine the single-pixel ground sample area from geostationary orbit.

A small, high-reliability, space-proven cryocooler cools the focal plane array and a portion of the optics module. Instrument control electronics provide the functionality to receive communications (commands) from the host spacecraft, control the instrument, sequence the data collection operations and ultimately send science data to the host for downlink.

Figure 10 shows the image collection timing between a gas cell and its physically adjacent paired vacuum cell on a continuously rotating wheel. When an unobscured FOV emerges as a cell rotates through the optical path, the focal plane collects an image of the entire physical domain using one of two integration times (corresponding to low gain and high gain). Multiple gains are necessary to image the high dynamic range across the entire FOV with the required SNR. Only $60 \mathrm{~ms}$ later, the FOV of the next cell (a vacuum cell in the case of Fig. 10) is unobscured, and the focal plane collects an image. The short $60 \mathrm{~ms}$ between images effectively freezes the scene, allowing the GFCR algorithm to process the pair cell and vacuum signals together without geometric corrections, providing nearly simultaneous gas and vacuum cell views described in Sect. 3.1. Single frames of paired gas and vacuum cell signals, as described above, are continuously collected until a prescribed number of images have been collected for each gas-vacuum cell pair. All of the images are downlinked through the host spacecraft. In ground processing, the single-frame Level 0 (signal count) data are processed for image registration and radiance calibration before being co-added to build up the required signal-to-noise ratio for the Level 1 (radiance) measurement at each location (pixel). The full data collection sequence includes calibration views, the full Earth view image collection outlined above for both low and high gains, followed again by calibration. 


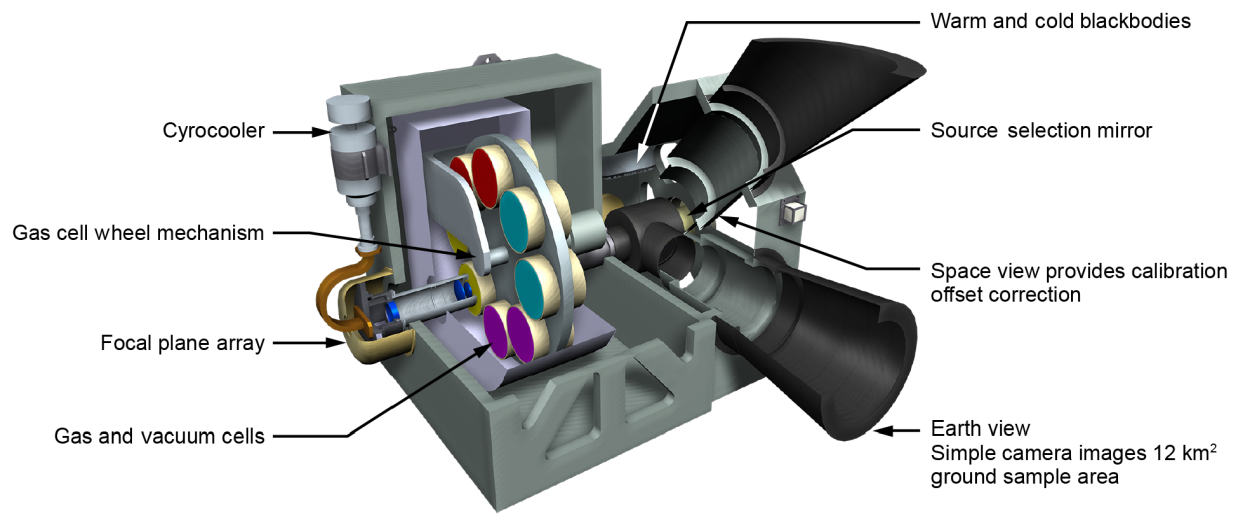

Figure 9. The CHRONOS GFCR is a staring infrared camera with gas cell filters in the optical path. A source selection mirror determines the input to the system (Earth FOV, one of three onboard calibration sources, deep space or closed). Optics image this source input onto a cryogenically cooled large-area focal plane array.

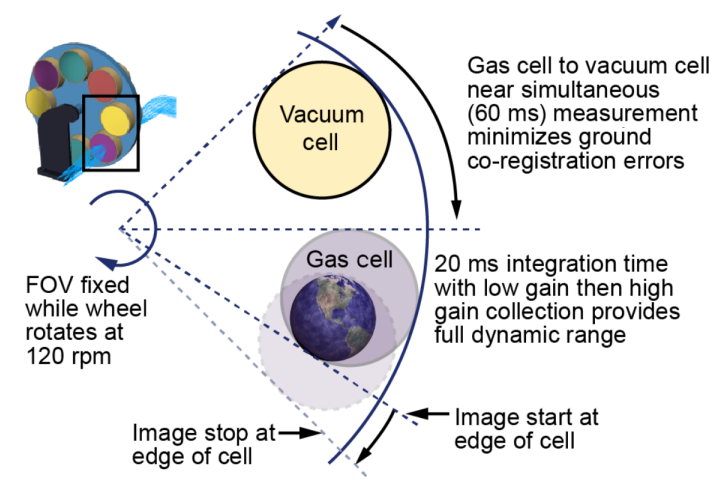

Figure 10. CHRONOS' eight gas cells are mounted in a continuously spinning mechanism wherein each cell in sequence exposes an unobscured Earth FOV as defined in Fig. 8. A single-frame image is collected with a prescribed integration time. Single frames are continuously collected and downlinked via the host spacecraft. In ground processing the ensemble of single frames are co-added to achieve the required signal-to-noise ratios for each measurement.

The required SNRs for all channels are achieved in $9.7 \mathrm{~min}$ of measurement time. The CHRONOS gas cell filter wheel rotates continuously, and data may be obtained continuously, for up to six full-precision data takes per hour. Parameter tables can be uploaded to alter this sequence or command additional data collections as necessary.

For on-orbit radiance calibration, CHRONOS views highprecision hot and cold blackbodies and deep space for the MWIR channels, and a tungsten lamp (LandSat Operational Land Imager heritage) and a closed aperture for the SWIR calibration within each $10 \mathrm{~min}$ data acquisition.

CHRONOS cloud detection will follow the MOPITT algorithm approach, which uses the MWIR $A$ signals as the primary test for the presence of cloud, based on observed brightness temperature (Warner et al., 2001). In the case of MOPITT operation, cloud flags are then verified with the Mod- erate Resolution Imaging Spectroradiometer (Terra/MODIS) cloud data products, when available. Using a similar approach, CHRONOS will use the GOES-R ABI cloud mask (Heidinger, 2011) to verify cloud detection. Cloud movement is assumed negligible during a $60 \mathrm{~ms}$ frame measurement. MOPITT retrieval experience shows that the GFCR technique can tolerate up to $\sim 5 \%$ cloud contamination and still treat the pixel as cloud-free (Warner et al., 2001). While the approach of using $D / A$ for retrievals discussed in Sect. 3.3 will cancel some of the errors due to undetected aerosols or clouds (e.g., thin cirrus), remaining retrievals errors (e.g., O'Dell et al., 2012), particularly for $\mathrm{CH}_{4}$, will require further study using both CHRONOS radiances and GOES-16 ABI observations. Combined with CHRONOS' sub-hourly revisit, the small nominal ground sample area increases the probability of obtaining cloud-free pixels in regions of broken cloud. This is an advantage compared to observations from LEO where a cloud-free scene may not be encountered at a given location over several days. Figure 11 shows OSSE results for simulated CHRONOS observations over a 2 -week summer period. This study indicates that $70-75 \%$ of $4 \mathrm{~km} \times 4 \mathrm{~km}$ pixels can be treated as cloud-free in the western and central U.S. and 60-65\% in the eastern U.S.

After cloud detection, the retrieval algorithm accesses current best meteorological analysis data for surface pressure and temperature, atmospheric temperature and water vapor profiles to include in the forward-model radiance calculation. A maximum a posteriori retrieval (Rodgers, 2000) is then used to convert Level 1 TOA radiances to Level 2 vertical trace gas distributions. 

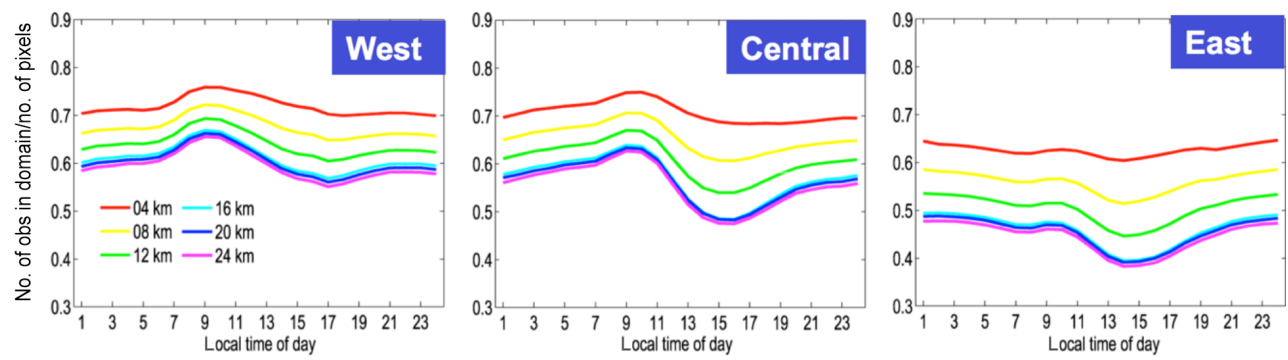

Figure 11. CONUS cloud statistics from OSSE results for 15-30 July 2006 using a high-spatial-resolution WRF-Chem run and a GFCR instrument with allowable pixel cloud fraction set at $3 \%$. For different geographical regions, the fraction of cloud-free scenes (the number of cloud-free pixels observed as a fraction of the total number of pixels in the region) is plotted for different assumed pixel sizes; red represents the CHRONOS $4 \mathrm{~km} \times 4 \mathrm{~km}$ pixels. Clouds are defined by $4 \mathrm{~km}$ grid-integrated total hydrometeors $>10^{-8} \mathrm{~kg} \mathrm{~kg}^{-1}$.

\section{Characterization of CHRONOS $\mathrm{CO}$ and $\mathrm{CH}_{4}$ retrievals}

\subsection{Multispectral CO measurements and vertical profile information}

CHRONOS CO measurements use MWIR thermal emission (day and night), with sensitivity to free-tropospheric $\mathrm{CO}$, and SWIR solar reflection (day), with sensitivity to total column CO. These measurements are combined in a multispectral retrieval to obtain vertical profiles of $\mathrm{CO}$ abundance (Fig. 12). Following MOPITT retrieval algorithms, CHRONOS will employ the maximum a posteriori methods of Rodgers (2000), which provide an averaging kernel (AK) that represents the sensitivity of the retrieval to the abundance of the target trace gas in each retrieval pressure layer in $\log _{10}$ of volume mixing ratio (Deeter et al., 2007). The single-pixel retrieval results depend on both the choice of a priori profile and a priori error covariance, and retrieval diagnostics such as the averaging kernel and the posterior error covariance depend on the a priori error covariance. MOPITT retrieval algorithms, since version 4, have applied spatially and monthly (but not yearly) varying a priori profiles from a model climatology, and a single prior error covariance with diagonal values corresponding to $30 \%$ variability in fractional volume mixing ratio and a correlation height (off-diagonal variation) of $100 \mathrm{hPa}$ (Deeter et al., 2010). CHRONOS retrievals will emulate the MOPITT retrieval approach to facilitate comparisons and analyses of long-term changes in $\mathrm{CO}$.

Degrees of freedom for signal (DFS) in the retrieval are computed from the trace of the AK and provide a measure of the independent profile information available. DFS values are $\sim 1.5$ to 2 for retrievals using only MWIR channels with $\mathrm{CO}$ gas cells at two different pressures, while a column retrieval with the SWIR channel alone has at most a DFS of 1. The CHRONOS multispectral retrievals have DFS values typically $>2$. Figure 13 shows $\mathrm{CO}$ retrieval results from MOPITT that compare the sensitivity of MWIRonly, SWIR-only and multispectral retrievals. We note that MOPITT retrievals would have higher values of DFS with-

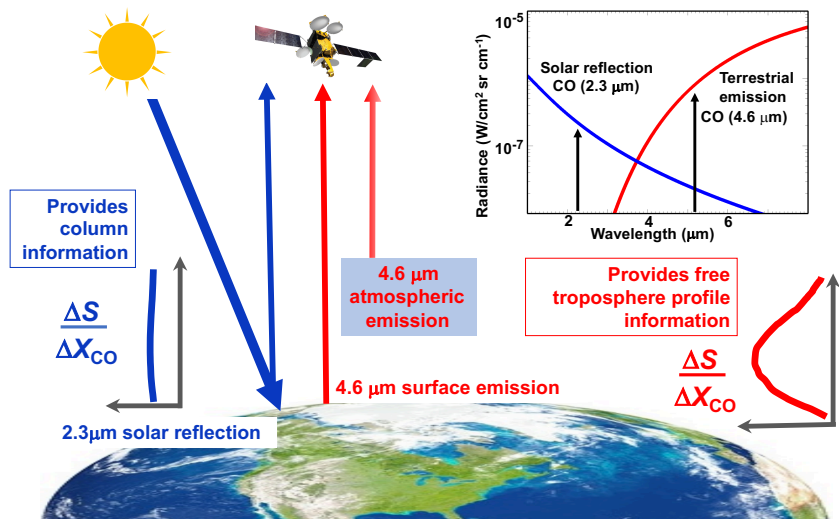

Figure 12. Physics of CHRONOS and MOPITT multispectral measurements. In the SWIR at 2.2 and $2.3 \mu \mathrm{m}$, measurement signals rely on daytime reflected solar radiation and weak spectral features. Changes in $\mathrm{CH}_{4}$ and $\mathrm{CO}$ mixing ratios, $\Delta X$, produce uniform signal sensitivity, $\Delta S$, throughout the vertical profile, including near the surface. In the MWIR at $4.6 \mu \mathrm{m}$, signal sensitivity is greatest in the middle troposphere, except in cases of high thermal contrast between the surface and the lowest atmospheric layers. CHRONOS $\mathrm{CH}_{4}$ SWIR retrievals use the solar reflection radiance to provide a true total column, and $\mathrm{CO}$ multispectral retrievals combine the SWIR and MWIR measurements to increase the sensitivity to nearsurface CO. While this increased sensitivity varies depending on scene characteristics such as albedo, in many cases, it provides improved information to distinguish local air pollution emissions and transported plumes.

out the presence of geophysical noise in MOPITT observations (Deeter et al., 2011). Geophysical noise is introduced by changes in the FOV surface albedo due to LEO spacecraft motion during the time taken for MOPITT signal acquisition. The CHRONOS stationary FOV and single-frame integration time of $20 \mathrm{~ms}$ mitigates this source of noise. Multispectral CO retrievals from MOPITT have demonstrated the improvements in sensitivity to surface layer CO abundance (Worden et al., 2010), have been validated (Deeter et al., 2011, 2013) and have been used in many studies to distinguish surface 

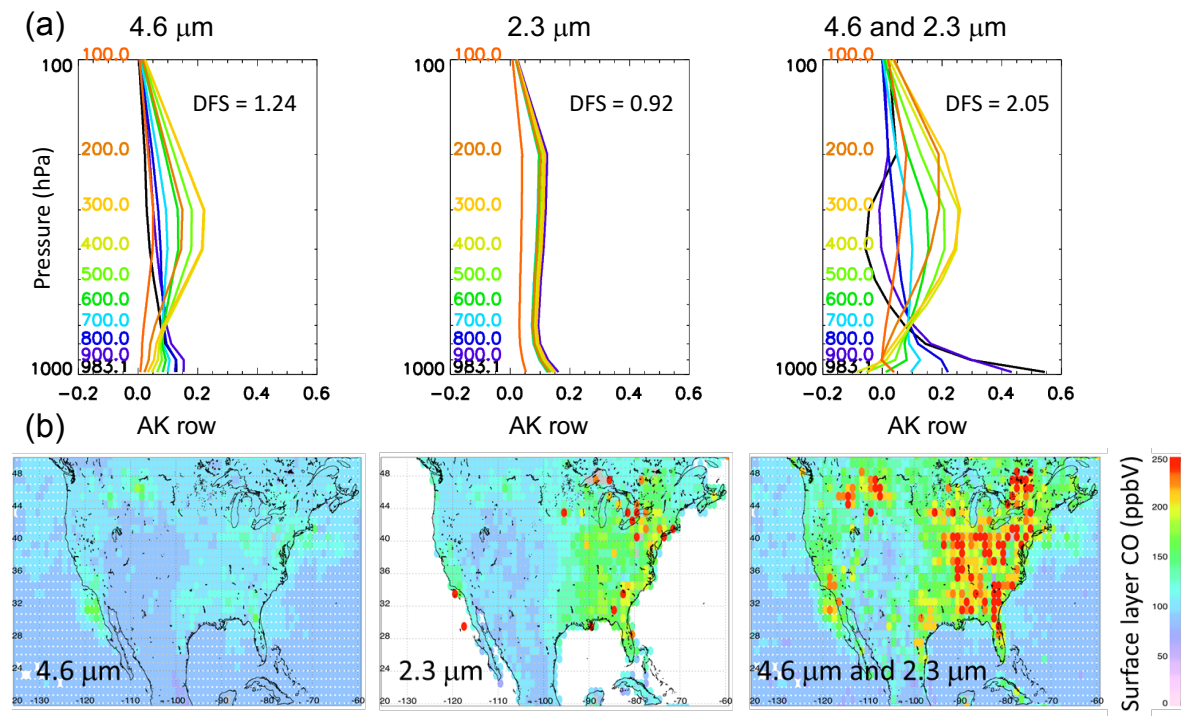

Figure 13. Comparison of surface layer CO for MOPITT version 7 data (Deeter et al., 2017) MWIR (4.6 $\mu \mathrm{m}), \mathrm{SWIR}(2.3 \mu \mathrm{m})$ and multispectral (MWIR and SWIR combined) retrievals for August 2000. Top panels show representative averaging kernel (AK) rows, where line colors indicate the pressure layers given on the left side of the panels, for the three retrieval types (location at $30.72^{\circ} \mathrm{N}, 96.50^{\circ} \mathrm{W}$ ). Bottom panels show maps of the surface layer $\mathrm{CO}$ abundance indicating how detailed information is obtained in the multispectral retrievals but is absent in the single-channel retrievals.

pollution emissions from transported plumes (e.g., Worden et al., 2012; Jiang et al., 2013, 2015; He et al., 2013; Silva et al., 2013; J. Worden et al., 2013a; Huang et al., 2013; Anderson et al., 2014; Bloom et al., 2015). The CHRONOS multispectral retrievals would extend the MOPITT record of vertical layers of $\mathrm{CO}$ over North America when MOPITT is finally decommissioned, since MOPITT is the only satellite mission to demonstrate multispectral trace gas retrievals from a single space-based instrument. The multispectral retrieval approach for $\mathrm{CO}$ allows for up to $3 \mathrm{DFS}$, which is a practical upper limit on $\mathrm{CO}$ vertical information based on atmospheric radiative transfer. As has been demonstrated by other on-orbit sensors measuring $\mathrm{CO}$, an instrument design with more gas cells, or a spectrometer with arbitrarily fine spectral resolution (George et al., 2009), does not produce retrievals with greater DFS. Thus, CHRONOS would produce the maximum vertical information possible for $\mathrm{CO}$ with a passive sensor.

\subsection{Retrieval sensitivity to near-surface $\mathrm{CH}_{4}$}

The vertical profiles of $\mathrm{CH}_{4}$ are similarly characterized using the AK from maximum a posteriori retrievals (Rodgers, 2000). Radiative transfer modeling has been developed to compute weighting functions, i.e., radiance Jacobians integrated over the filter band pass, to assess the sensitivity to changes in the $\mathrm{CH}_{4}$ column. Figure 14 shows an example of a simulated $\mathrm{CHRONOS} \mathrm{CH}_{4}$ weighting function and corresponding AK (see caption for simulation assumptions). For the SWIR measurements, the signal source is solar reflectance with a measurement sensitivity response that is nearly uniform in the vertical, giving true total column $\mathrm{CH}_{4}$ information with DFS close to 1 .

The magnitude and shape of the column $\mathrm{CH}_{4} \mathrm{AKs}$ have only small variations with input atmospheric parameters (such as temperature and water vapor) and input surface parameters such as albedo (assuming non-zero albedo). However, there is a more significant dependence of the $\mathrm{CH}_{4} \mathrm{AK}$ on parameters that depend on the total amount of $\mathrm{CH}_{4}$ along the observation path, such as solar zenith angle (SZA), satellite zenith angle and $\mathrm{CH}_{4}$ abundance. Figure 15 shows how the sensitivity to $\mathrm{CH}_{4}$ in the lowest (near-surface) layer depends on SZA for $A, D$ and $D / A$ signals. While the $A$ and $D$ signals both have reduced sensitivity with higher SZA, as expected for solar reflection radiances, the $D / A$ ratio sensitivity increases slightly, with relatively uniform response, for daylight hours. Figure 16 shows the dependence of $\mathrm{CH}_{4}$ AKs on SZA and $\mathrm{CH}_{4}$ total column, with sensitivity to surface $\mathrm{CH}_{4}$ that increases with increasing values, especially for SZA, as expected from Fig. 15.

\section{Relationship of CHRONOS to current and future missions}

CHRONOS addresses key NASA science goals and National Research Council decadal survey questions with heritage from past satellite instruments and opportunities for synergistic observations with current and upcoming LEO and GEO platforms. In particular, CHRONOS would complement planned NASA missions for air quality and carbon cy- 

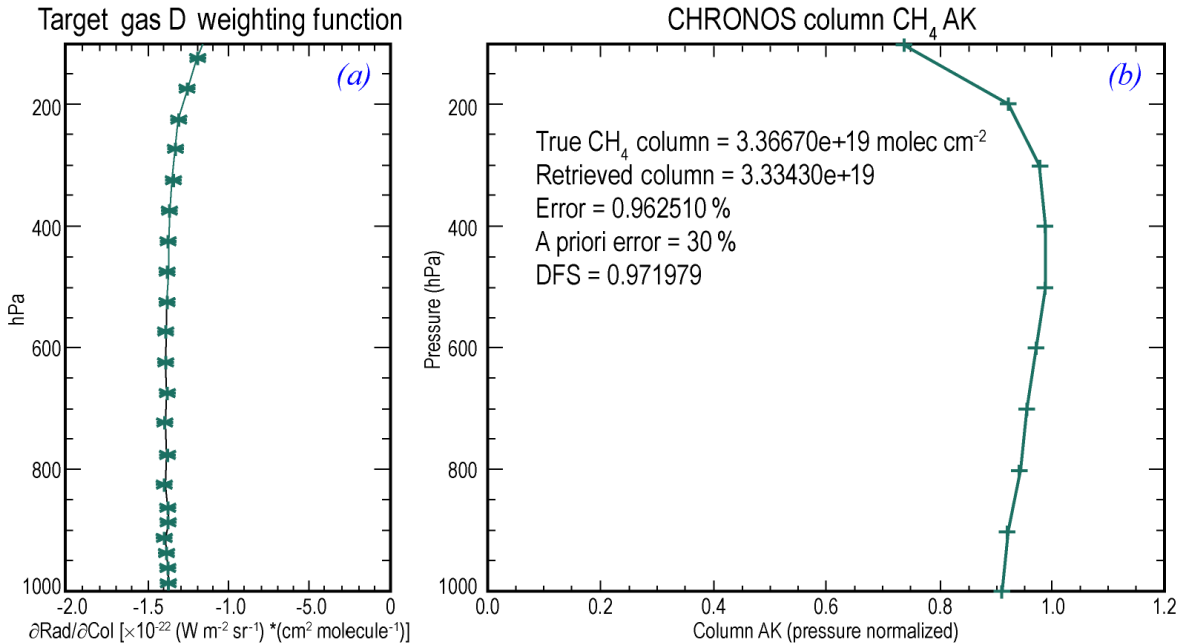

Figure 14. CHRONOS $\mathrm{CH}_{4} D$-signal weighting function and retrieval column AK. (a) Sensitivity of the $D$ signal to changes in $\mathrm{CH}_{4}$ column $(\operatorname{Rad}(D) / \partial \operatorname{col})$ as a function of vertical pressure for a standard midlatitude summer atmosphere with albedo $=0.1, \mathrm{SZA}=0^{\circ}$ and satellite $\mathrm{ZA}=40^{\circ}$. (b) The retrieval column averaging kernel from the corresponding $D / A$ signal ratio and Jacobian. This assumes CHRONOS measurement precision and a priori covariance with $30 \%$ diagonal errors and $500 \mathrm{hPa}$ correlation length (retrieval was performed on a coarser pressure grid than the weighting function calculations). Since the signal source is solar reflectance, the response is nearly uniform vertically with DFS close to 1 .

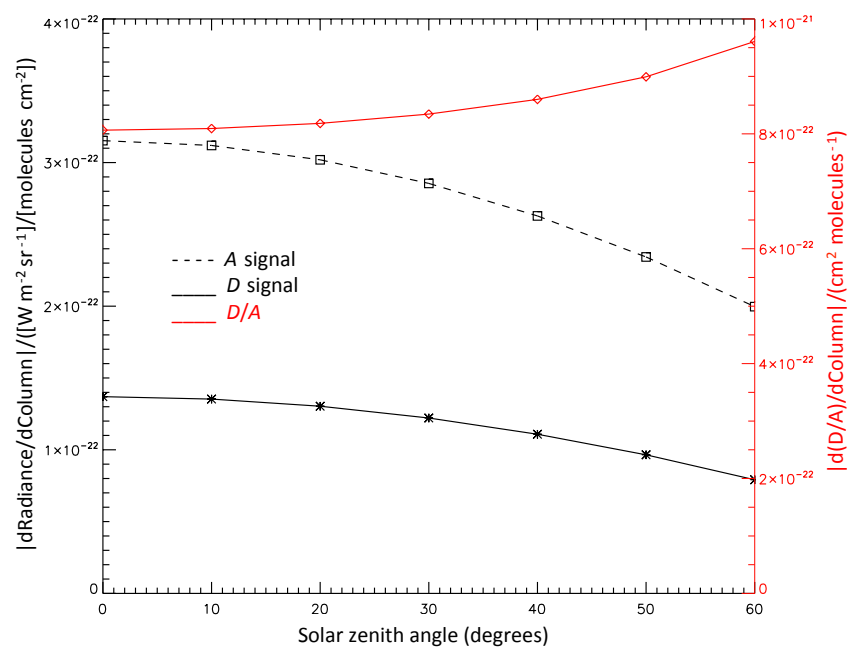

Figure 15. Variation of CHRONOS sensitivity to surface $\mathrm{CH}_{4}$ with solar zenith angle (SZA). Absolute values for the surface layer $\mathrm{CH}_{4}$ Jacobians are plotted for the $A$ signal, $D$ signal and $D / A$ ratio as a function of SZA.

cle science. It would deliver air pollutant measurements identified in the 2007 decadal survey GEO-CAPE mission (NRC, 2007) and address currently unmet science objectives described in the GEO-CAPE Science Traceability Matrix (Fishman et al., 2012).

\subsection{Other satellite $\mathrm{CO}$ observations}

Along with MOPITT, satellite measurements of $\mathrm{CO}$ in the MWIR $(4.6 \mu \mathrm{m})$ are available from AIRS, a grating spectrometer on EOS-Aqua launched in 2002 (Auman et al., 2003); the IASI FTS instruments on MetOp-A, -B and -C, launched in 2006 and 2012 and expected in 2018 (Crevoisier et al., 2014); and the CrIS FTS instruments on Suomi NPP, launched 2011, and JPSS1-4 with projected launches starting in 2017 (Gambacorta et al., 2014). These LEO observations give daily global coverage at morning (IASI) and afternoon (AIRS, CrIS) Equator crossings with sensitivity to $\mathrm{CO}$ in the middle troposphere for most observing conditions (George et al., 2009). The measurements are expected to be available during the CHRONOS mission time frame and will provide valuable intercomparisons for the MWIR CHRONOS CO channel.

TROPOMI, a UV-VIS-NIR-SWIR (NIR: near-infrared) spectrometer, launched in October 2017, provides daily global coverage from LEO at a 13:30 Equator crossing with $7 \mathrm{~km} \times 7 \mathrm{~km}$ spatial resolution and $10 \%$ column precision and $15 \%$ accuracy for SWIR $(2.3 \mu \mathrm{m}) \mathrm{CO}$ observations (Veefkind et al., 2012). The TROPOMI CO measurements will provide true total column $\mathrm{CO}$ retrievals with more spatial coverage than MOPITT but will not have MOPITT's CO vertical profile information. GOSAT-2 (http:// www.gosat-2.nies.go.jp), with expected launch in 2018, will also measure SWIR CO bands but with measurements spaced around $200 \mathrm{~km}$ apart and large gaps in the ground sampling. CHRONOS multispectral $\mathrm{CO}$ measurements could provide vertical profiles of $\mathrm{CO}$ over the continental U.S. domain ev- 


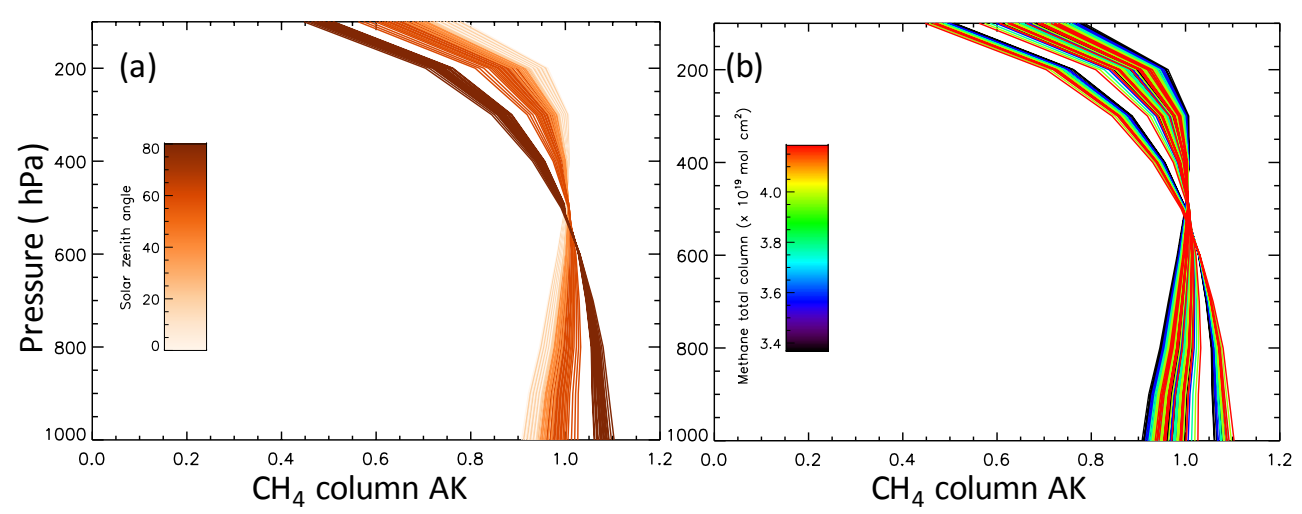

Figure 16. Variation of CHRONOS $\mathrm{CH}_{4}$ averaging kernels for different SZA (a) and $\mathrm{CH}_{4}$ total column (b) for 100 simulations with different SZA and $\mathrm{CH}_{4}$ column values. Within each "group" of SZA values, the lesser AK dependence on low-to-high values of $\mathrm{CH}_{4}$ can be seen.

ery $10 \mathrm{~min}$, along with total column CO that can be compared to TROPOMI and GOSAT-2. The LEO observations of CO outside of the CHRONOS field of regard would be useful for constraining $\mathrm{CO}$ transported from sources outside North America.

NASA selected the Geostationary Carbon Cycle Observatory (GeoCARB) mission in November 2016, with capability to measure CO in one spectral region (Polonsky et al., 2014; Kumer et al., 2013) and primary carbon cycle science objectives unrelated to air pollution transport. Compared to the CHRONOS requirement for $\mathrm{CO}$ measurement in two spectral regions, this GeoCARB limitation to $\mathrm{CO}$ in one spectral region precludes GeoCARB from evaluating vertical pollution transport, or providing the test of these atmospheric motions as calculated by models. Both Polonsky et al. (2014) and Kumer et al. (2013) describe mission descopes that eliminate GeoCARB measurements of $\mathrm{CO}$ entirely if needed to ensure success for GeoCARB $\mathrm{CO}_{2}$ and solar-induced fluorescence science objectives.

\subsection{Other satellite $\mathrm{CH}_{4}$ observations}

GOSAT, launched in 2009, measures $\mathrm{CH}_{4}$ from LEO in the SWIR $(1.6 \mu \mathrm{m})$, with relatively sparse coverage, a $10 \mathrm{~km}$ diameter footprint and column precision around $0.6 \%$ for single observations (Schepers et al., 2012). Improved sampling, coverage and precision are expected for GOSAT-2. Wecht et al. (2014a) show that hourly GEO SWIR $\mathrm{CH}_{4}$ observations over California with $4 \mathrm{~km} \times 4 \mathrm{~km}$ spatial resolution and $1.1 \%$ precision provide about 20 times the information for estimating $\mathrm{CH}_{4}$ emissions compared to 3 days of GOSAT observations. This means that one 10 min collection of CHRONOS data would provide more information than a year of GOSAT observations, assuming $1 / \sqrt{N}$ improvement for 365 days. A. J. Turner et al. (2015) used 3 years (20092011) of GOSAT $\mathrm{CH}_{4}$ measurements to estimate North American emissions with $1 / 2^{\circ} \times 2 / 3^{\circ}(\sim 50 \mathrm{~km} \times 70 \mathrm{~km})$ spatial resolution and found significant differences with the a priori inventory for anthropogenic emissions. Assuming the same information scaling found by Wecht et al. (2014a), CHRONOS would be able to quantify $\mathrm{CH}_{4}$ emissions for this spatial scale on a daily basis, with the capability to assess more rapid emission changes for events such as the $2015 \mathrm{Al}-$ iso Canyon gas leak (Conley et al., 2016).

TROPOMI in LEO uses NIR $(0.76 \mu \mathrm{m}) \mathrm{O} 2-\mathrm{A}$ and SWIR $(2.3 \mu \mathrm{m})$ bands for $\mathrm{CH}_{4}$ measurements and has an expected $0.6 \%$ precision for single-column $\mathrm{CH}_{4}$ retrievals at $7 \mathrm{~km} \times 7 \mathrm{~km}$ spatial resolution (Butz et al., 2012). Based on an analysis in Jacob et al. (2016), TROPOMI should be capable of regional-scale quantification of $\mathrm{CH}_{4}$ emissions. The daily probability of viewing sources that are either transient or obscured by clouds would be higher for CHRONOS in GEO than for TROPOMI, since CHRONOS could observe the entire continental U.S. domain six times during each daylight hour. CHRONOS also has a higher probability of cloudfree observations given its smaller pixel size (see Fig. 11).

GeoCARB describes $\mathrm{CH}_{4}$ measurements in the SWIR $(2.3 \mu \mathrm{m})$ region with $1 \%$ precision three times per day at $5 \mathrm{~km} \times 5 \mathrm{~km}$ spatial resolution (O'Brien et al., 2016), although earlier studies (Kumer et al., 2013) explored $\mathrm{CH}_{4}$ measurements at $1.65 \mu \mathrm{m}$. GeoCARB's more frequent $\mathrm{CH}_{4}$ observations than TROPOMI may provide for similar precision in a smaller spatial footprint than TROPOMI. CHRONOS could observe $\mathrm{CH}_{4}$ as often as every $10 \mathrm{~min}$ in daylight with $0.7 \%$ precision and $4 \mathrm{~km} \times 4 \mathrm{~km}$ resolution. These frequent CHRONOS $\mathrm{CH}_{4}$ measurements could be coadded to improve hourly precision, or used to examine anthropogenic source evolution over time.

For emissions on a $1 / 2^{\circ} \times 2 / 3^{\circ}$ grid, Wecht et al. (2014a) show that GEO-CAPE SWIR $\mathrm{CH}_{4}$ hourly observations (assuming $1.1 \%$ column precision) have 2.4 times the information of daily TROPOMI for estimating $\mathrm{CH}_{4}$ emissions. More work is needed using OSSEs to understand how to optimally exploit LEO observations of $\mathrm{CH}_{4}$ and $\mathrm{CO}$, especially from TROPOMI and GOSAT-2, in combination with the information on diurnal variability that CHRONOS could provide. 
Table 3. Relationship of CHRONOS to current and future $\mathrm{CO}$ and $\mathrm{CH}_{4}$ missions. CHRONOS contributes unique observations of multispectral $\mathrm{CO}$ for tracing air pollution transport and temporally dense $\mathrm{CH}_{4}$ observations to improve emissions estimates across a continental domain.

\begin{tabular}{|c|c|c|c|c|c|c|}
\hline Instrument & MOPITT & TROPOMI & TANSO-FTS-2 & $\begin{array}{l}\text { Sentinel- } \\
5 / \text { UVNS }\end{array}$ & GeoCARB & CHRONOS \\
\hline Instrument type & $\begin{array}{l}\text { Gas filter } \\
\text { correlation } \\
\text { radiometer }\end{array}$ & $\begin{array}{l}\text { Grating } \\
\text { spectrometer }\end{array}$ & $\begin{array}{l}\text { Fourier } \\
\text { transform } \\
\text { spectrometer }\end{array}$ & $\begin{array}{l}\text { Grating } \\
\text { spectrometer }\end{array}$ & $\begin{array}{l}\text { Grating } \\
\text { spectrometer }\end{array}$ & $\begin{array}{l}\text { Gas filter } \\
\text { correlation } \\
\text { radiometer }\end{array}$ \\
\hline Spacecraft & NASA Terra & $\begin{array}{l}\text { ESA Sentinel- } \\
5 P\end{array}$ & GOSAT-2 & MetOp SG A1 & Commercial & Proposed \\
\hline Launch Date & 1999 & 2017 & 2018 & 2021 & 2022 & NET 2024 \\
\hline Source of Info & $\begin{array}{l}\text { Drummond et } \\
\text { al. (2010) }\end{array}$ & $\begin{array}{l}\text { ATBD } \\
\text { (Veefkind } \\
\text { et al., 2012) }\end{array}$ & $\begin{array}{l}\text { Matsunaga et } \\
\text { al. (2017) }\end{array}$ & $\begin{array}{l}\text { Ingmann et al. } \\
\text { (2012) }\end{array}$ & $\begin{array}{l}\text { O'Brien et al. } \\
(2016)\end{array}$ & This work \\
\hline Orbit & LEO SSO & LEO SSO & LEO SSO & LEO SSO & GEO & GEO \\
\hline Domain & Near global & Near global & Near global & Near global & $\begin{array}{l}\text { North/South } \\
\text { America }\end{array}$ & North America \\
\hline Pixel size, $\mathrm{km}^{2}$ & $22 \times 22$ & $7 \times 7$ & $9.7 \times 9.7$ & $7.5 \times 7.5$ & $5 \times 5$ & $4 \times 4$ \\
\hline Revisit & 3 days & Daily & 6 days & Daily & 3x/day & Sub-hourly* \\
\hline $\begin{array}{l}\mathrm{CH}_{4} \text { spectral } \\
\text { region, } \mu \mathrm{m}\end{array}$ & $2.222-2.293$ & $2.303-2.385$ & $\begin{array}{l}1.563-1.695 \\
5.56-8.45\end{array}$ & $1.590-1.675$ & $2.301-2.346$ & $2.250-2.313$ \\
\hline $\begin{array}{l}\mathrm{CH}_{4} \text { column } \\
\text { precision, \% }\end{array}$ & - & 0.6 & 0.6 & 1 & 0.6 & 0.7 \\
\hline CO spectral & $2.323-2.345$ & $2.303-2.385$ & $1.923-2.381$ & $2.305-2.385$ & $2.301-2.346$ & $2.313-2.364$ \\
\hline regions, $\mu \mathrm{m}$ & $4.562-4.673$ & - & - & - & - & $4.562-4.673$ \\
\hline $\begin{array}{l}\text { CO column } \\
\text { precision, \% }\end{array}$ & 10 & 10 & 10 & 10 & 10 & 10 \\
\hline
\end{tabular}

* Up to 6 observations per hour.

This extends to examination of the North American carbon budget since $\mathrm{CO}$ and $\mathrm{CH}_{4}$ measurements from CHRONOS, in conjunction with detailed $\mathrm{CO}_{2}$ observations from planned and operating missions, would allow differentiation of anthropogenic combustion and wildfire sources of $\mathrm{CO}_{2}$.

Missions with the ability to measure true columns for $\mathrm{CO}$ and/or $\mathrm{CH}_{4}$ (i.e., using SWIR spectra for the measurement) are summarized in Table 3. Note that, for CHRONOS, $10 \%$ precision on CO observations meets the GEO-CAPE CO precision requirement of 10 ppbv. The CHRONOS $0.7 \%$ precision for $\mathrm{CH}_{4}$ observations is achieved in a single $9.7 \mathrm{~min}$ data collection; improved precision can be achieved by combining multiple data collections.

\section{Conclusions}

We report a new capability for space-based measurements of the important air pollutants carbon monoxide $(\mathrm{CO})$ and methane $\left(\mathrm{CH}_{4}\right)$ as often as six times per hour. $\mathrm{CO}$ and $\mathrm{CH}_{4}$ abundance are chemically linked in Earth's atmosphere as the principal sinks of hydroxyl. Sub-hourly observations of CO abundance, which is highly variable in space and time, can reveal new knowledge of the vertical and horizontal transport of air pollution. When sub-hourly observations of more slowly varying $\mathrm{CH}_{4}$ abundance are combined, the temporally dense observations can significantly improve the precision of $\mathrm{CH}_{4}$ emissions estimates. OSSESs reported elsewhere show that improved $\mathrm{CO}$ and $\mathrm{CH}_{4}$ emissions estimates can improve air quality forecasts that protect public health.

The CHRONOS investigation using 2-D imaging with full spectral resolution would contribute the only sub-hourly $\mathrm{CO}$ and $\mathrm{CH}_{4}$ observations for the U.S. component of an international GEO satellite constellation for atmospheric composition (CEOS, 2011) that includes the ESA/EUMETSAT Sentinel-4 mission over Europe and the Korean MPGEOSAT/GEMS over Asia, along with the NASA TEMPO mission. LEO components (Sentinel-5/UVNS, TROPOMI, GOSAT-2) of the constellation provide the global context (Table 3) for CHRONOS observations in assessing regionalto-global emissions and transport.

The main points defining the CHRONOS science investigation may be summarized as follows:

1. CHRONOS would deliver the first sub-hourly observation capability for comprehensive U.S. $\mathrm{CH}_{4}$ and $\mathrm{CO}$ emission inventories and the ability to distinguish local from transported air pollution.

2. At the county scale, CHRONOS would enable new estimates of rapidly changing, highly variable $\mathrm{CH}_{4}$ and 
$\mathrm{CO}$ emissions from growing natural gas extraction and increasingly frequent and severe wildfires. These emissions estimates are essential for air quality, climate, and energy management decisions.

3. The dense data from sub-hourly air pollution observations at fine spatial resolution (nominally $4 \mathrm{~km} \times 4 \mathrm{~km}$ ) over the entire greater North American domain would quantify diurnal changes in air pollution and discriminate different source regions for urban and rural emission activities.

4. CHRONOS' multispectral CO retrieval would provide vertical information near the surface in addition to the free troposphere to distinguish local air pollution from transported air pollution through horizontal and vertical tracking.

5. CHRONOS observations would strengthen the international air quality satellite constellation.

These science goals would be achieved by taking advantage of a simple, low-risk instrument design that is well suited to the CHRONOS $\mathrm{CO}$ and $\mathrm{CH}_{4}$ measurements. The GCFR heritage follows the successful 17-year, on-orbit operation of MOPITT over a wide range of observing conditions. This technique provides for high effective spectral resolution for the target gases; high signal levels compared to other types of spectrometers with similar spectral sensitivity; and small impact from signals due to interfering gases, aerosols, clouds and changing scene.

Data availability. MOPITT data used in this manuscript are public and available at https://eosweb.larc.nasa.gov/ (MOPITT Science Team, 2013).

Competing interests. The authors declare that they have no conflict of interest.

Acknowledgements. This work was partly supported by NASA grant NNX15AK98G. The National Center for Atmospheric Research (NCAR) is sponsored by the National Science Foundation. The NCAR MOPITT project is supported by the NASA Earth Observing System program. We thank Glenn Diskin and the DACOM measurement team at NASA Langley for providing the DISCOVER-AQ $\mathrm{CH}_{4}$ measurements shown in Fig. 3.

Edited by: Andre Butz

Reviewed by: three anonymous referees

\section{References}

Abatzoglou, J. T. and Williams, A. P.: Impact of anthropogenic climate change on wildfire across western US forests, P. Natl. Acad. Sci. USA, 113, 11770-11775, https://doi.org/10.1073/pnas.1607171113, 2016.

Acton, L. L., Griggs, M., Hall, G. D., Ludwig, C. B., Malkmus, W., Hesketh, W. D., and Reichle, H.: Remote measurement of carbon monoxide by a gas filter correlation instrument, AIAA Journal, 11, 899-900, 1973.

Allen, D. T., Torres, V. M., Thomas, J., Sullivan, D. W., Harrison, M., Hendler, A., Herndon, S. C., Kolb, C. E., Fraser, M. P., Hill, A. D., and Lamb, B. K.: Measurements of methane emissions at natural gas production sites in the United States, P. Natl. Acad. Sci. USA, 110, 17768-17773, https://doi.org/10.1073/pnas.1304880110, 2013.

Anderson, D. C., Loughner, C. P., Diskin, G., Weinheimer, A., Canty, T. P., Salawitch, R. J., Worden, H. M., Fried, A., Mikoviny, T., Wisthaler, A., and Dickerson, R. R.: Measured and modeled CO and NOy in DISCOVER-AQ: An evaluation of emissions and chemistry over the eastern US, Atmos. Environ., 96, 78-87, https://doi.org/10.1016/j.atmosenv.2014.07.004, 2014.

Anderson, G. P., Clough, S. A., Kneizys, F. X., Chetwynd, J. H., and Shettle, E. P.: AFGL atmospheric constituent profiles (0-120 km), AFGL-TR-86-0110, AFGL(OPI), Air Force Geophysics Laboratory, Hanscom Air Force Base, MA 01736, USA, 1986.

Angelbratt, J., Mellqvist, J., Blumenstock, T., Borsdorff, T., Brohede, S., Duchatelet, P., Forster, F., Hase, F., Mahieu, E., Murtagh, D., Petersen, A. K., Schneider, M., Sussmann, R., and Urban, J.: A new method to detect long term trends of methane $\left(\mathrm{CH}_{4}\right)$ and nitrous oxide $\left(\mathrm{N}_{2} \mathrm{O}\right)$ total columns measured within the NDACC ground-based high resolution solar FTIR network, Atmos. Chem. Phys., 11, 6167-6183, https://doi.org/10.5194/acp-11-6167-2011, 2011.

Arellano, A. F., Hess, P. G., Edwards, D. P., and Baumgardner, D.: Constraints on black carbon aerosol distribution from Measurement of Pollution in the Troposphere (MOPITT) CO, Geophys. Res. Lett., 37, L17801, https://doi.org/10.1029/2010g1044416, 2010.

Aumann, H. H., Chahine, M. T., Gautier, C., Goldberg, M. D., Kalnay, E., McMillin, L., M., Revercomb, H., Rosenkranz, P. W., Smith, W. L., Staelin, D. H., Strow, L. L., and Susskind, J.: AIRS/AMSU/HSB on the Aqua mission: Design, science objectives, data products, and processing systems, IEEE T. Geosci. Remote, 41, 253-264, 2003.

Barth, M. C., Lee, J., Hodzic, A., Pfister, G., Skamarock, W. C., Worden, J., Wong, J., and Noone, D.: Thunderstorms and upper troposphere chemistry during the early stages of the 2006 North American Monsoon, Atmos. Chem. Phys., 12, 11003-11026, https://doi.org/10.5194/acp-12-11003-2012, 2012.

Beer, R.: Remote Sensing by Fourier Transform Spectrometry, Wiley, New York, USA, 1992.

Bergamaschi, P., Frankenberg, C., Meirink, J. F., Krol, M., Dentener, F., Wagner, T., Platt, U., Kaplan, J. O., Körner, S., Heimann, M., and Dlugokencky, E. J.: Satellite chartography of atmospheric methane from SCIAMACHY on board ENVISAT: 2. Evaluation based on inverse model simulations, J. Geophys. Res.-Atmos., 112, D02304, https://doi.org/10.1029/2006jd007268, 2007.

Bergamaschi, P., Frankenberg, C., Meirink, J. F., Krol, M., Villani, M. G., Houweling, S., Dentener, F., Dlugokencky, E. J., 
Miller, J. B., Gatti, L. V., and Engel, A.: Inverse modeling of global and regional $\mathrm{CH}_{4}$ emissions using SCIAMACHY satellite retrievals, J. Geophys. Res.-Atmos., 114, D22301, https://doi.org/10.1029/2009jd012287, 2009.

Bian, H., Chin, M., Kawa, S. R., Yu, H., Diehl, T., and Kucsera, T.: Multiscale carbon monoxide and aerosol correlations from satellite measurements and the GOCART model: Implication for emissions and atmospheric atmospheric evolution, J. Geophys. Res.-Atmos., 115, D07302, https://doi.org/10.1029/2009jd012781, 2010.

Bloom, A. A., Worden, J., Jiang, Z., Worden, H., Kurosu, T., Frankenberg, C., and Schimel, D.: Remote-sensing constraints on South America fire traits by Bayesian fusion of atmospheric and surface data, Geophys. Res. Lett., 42, 1268-1274, https://doi.org/10.1002/2014GL062584, 2015.

Bohren, C. F. and Huffman, D. R.: Absorption and Scattering of Light by Small Particles, John Wiley and Sons, New York, USA, 1983.

Bousserez, N., Henze, D. K., Rooney, B., Perkins, A., Wecht, K. J., Turner, A. J., Natraj, V., and Worden, J. R.: Constraints on methane emissions in North America from future geostationary remote-sensing measurements, Atmos. Chem. Phys., 16, 61756190, https://doi.org/10.5194/acp-16-6175-2016, 2016.

Breul, H. and Doman, L.: U.S. Expected to be Largest Producer of Petroleum and Natural Gas Hydrocarbons in 2013, Today in Energy, available at: http://www.eia.gov/todayinenergy/detail.cfm? id=13251 (last access: 30 March 2017), 2013.

Brown, M. G., Baker, J., Colonero, C., Costa, J., Gardner, T., Kelly. M., Schultz, K., Tyrrell, B., and Wey, J.: Digital-pixel focal plane array development, Proc. SPIE 7608, Quantum Sensing and Nanophotonic Devices, VII, 76082H, https://doi.org/10.1117/12.838314, 2010.

Brunekreef, B. and Holgate, S. T.: Air pollution and health, Lancet, 360, 1233-1242, https://doi.org/10.1016/s0140-6736(02)112748, 2002.

Butz, A., Galli, A., Hasekamp, O., Landgraf, J., Tol, P., and Aben, I.: TROPOMI aboard Precursor Sentinel-5 Precursor: Prospective performance of $\mathrm{CH}_{4}$ retrievals for aerosol and cirrus loaded atmospheres, Remote Sens. Environ., 120, 267-276, https://doi.org/10.1016/j.rse.2011.05.030, 2012.

CEOS: A Geostationary Satellite Constellation for Observing Global Air Quality: An International Path Forward, available at: http://ceos.org/document_management/Virtual_Constellations/ ACC/Documents/ACC_White-Paper-A-Geostationary-SatelliteCx-for-Observing-Global-AQ-v4_Apr2011.pdf (last access: 30 March 2017), 2011.

Ciais, P., Sabine, C., Bala, G., Bopp, L., Brovkin, V., Canadell, J., Chhabra, A., DeFries, R., Galloway, J., Heimann, M., Jones, C., Le Qu éré, C., Myneni, R. B., Piao S., and Thornton P.: Carbon and Other Biogeochemical Cycles, in: Climate Change 2013: The Physical Science Basis. Contribution of Working Group I to the Fifth Assessment Report of the Intergovernmental Panel on Climate Change, edited by: Stocker, T. F., Qin, D., Plattner, G.-K., Tignor, M., Allen, S. K., Bosc Hung, J., Nauels, A., Xia, Y., Bex, B., and Midgley, P. M., Cambridge University Press, Cambridge, UK and New York, NY, USA, 465-570, https://doi.org/10.1017/CBO9781107415324.015, 2013.

Clerbaux, C., Boynard, A., Clarisse, L., George, M., Hadji-Lazaro, J., Herbin, H., Hurtmans, D., Pommier, M., Razavi, A., Turquety,
S., Wespes, C., and Coheur, P.-F.: Monitoring of atmospheric composition using the thermal infrared IASI/MetOp sounder, Atmos. Chem. Phys., 9, 6041-6054, https://doi.org/10.5194/acp-96041-2009, 2009.

Conley, S., Franco, G., Faloona, I., Blake, D. R., Peischl, J., and Ryerson, T. B.: Methane emissions from the 2015 Aliso Canyon blowout in Los Angeles, CA, Science, 351, 1317-1320, https://doi.org/10.1126/science.aaf2348, 2016.

Crevoisier, C., Clerbaux, C., Guidard, V., Phulpin, T., Armante, R., Barret, B., Camy-Peyret, C., Chaboureau, J.-P., Coheur, P.F., Crépeau, L., Dufour, G., Labonnote, L., Lavanant, L., HadjiLazaro, J., Herbin, H., Jacquinet-Husson, N., Payan, S., Péquignot, E., Pierangelo, C., Sellitto, P., and Stubenrauch, C.: Towards IASI-New Generation (IASI-NG): impact of improved spectral resolution and radiometric noise on the retrieval of thermodynamic, chemistry and climate variables, Atmos. Meas. Tech., 7, 4367-4385, https://doi.org/10.5194/amt-7-4367-2014, 2014.

Deeter, M. N., Emmons, L. K., Edwards, D. P., Gille, J. C., and Drummond, J. R.: Vertical resolution and information content of CO profiles retrieved by MOPITT, Geophys. Res. Lett., 31, 15112, https://doi.org/10.1029/2004GL020235, 2004.

Deeter, M. N., Edwards, D. P., and Gille, J. C.: Retrievals of carbon monoxide profiles from MOPITT observations using lognormal a priori statistics, J. Geophys. Res.-Atmos., 112, D11311, https://doi.org/10.1029/2006JD007999, 2007.

Deeter, M. N., Edwards, D. P., Gille, J. C., and Drummond, J. R.: CO retrievals based on MOPITT near-infrared observations, J. Geophys. Res.-Atmos., 114, D04303, https://doi.org/10.1029/2008JD010872, 2009.

Deeter, M. N., Edwards, D. P., Gille, J. C., Emmons, L. K., Francis, G., Ho, S.-P., Mao, D., Masters, D., Worden, H., Drummond, J. R., and Novelli, P. C.: The MOPITT version $4 \mathrm{CO}$ product: Algorithm enhancements, validation, and long-term stability, J. Geophys. Res.-Atmos., 115, D07306, https://doi.org/10.1029/2009JD013005, 2010.

Deeter, M. N., Worden, H. M., Gille, J. C., Edwards, D. P., Mao, D., and Drummond, J. R.: MOPITT multispectral CO retrievals: Origins and effects of geophysical radiance errors, J. Geophys. Res.Atmos., 116, D15303, https://doi.org/10.1029/2011JD015703, 2011.

Deeter, M. N., Martínez-Alonso, S., Edwards, D. P., Emmons, L. K., Gille, J. C., Worden, H. M., Pittman, J. V., Daube, B. C., and Wofsy, S. C.: Validation of MOPITT Version 5 thermal- infrared, near-infrared, and multispectral carbon monoxide profile retrievals for 2000-2011, J. Geophys. Res.-Atmos., 118, 6710 6725, https://doi.org/10.1002/jgrd.50272, 2013.

Deeter, M. N., Edwards, D. P., Francis, G. L., Gille, J. C., Martínez-Alonso, S., Worden, H. M., and Sweeney, C.: A climate-scale satellite record for carbon monoxide: the MOPITT Version 7 product, Atmos. Meas. Tech., 10, 2533-2555, https://doi.org/10.5194/amt-10-2533-2017, 2017.

Drummond, J. R., Zou, J., Nichitiu, F., Kar, J., Deschambaut, R., and Hackett, J.: A review of 9-year performance and operation of the MOPITT instrument, Adv. Space Res., 45, 760-774, https://doi.org/10.1016/j.asr.2009.11.019, 2010.

Edwards, D. P., Halvorson, C. M., and Gille, J. C.: Radiative transfer modeling for the EOS Terra satellite Measurement of Pollution in the Troposphere (MOPITT) in- 
strument, J. Geophys. Res.-Atmos., 104, 16755-16775, https://doi.org/10.1029/1999JD900167, 1999.

Edwards, D. P., Emmons, L. K., Hauglustaine, D. A., Chu, D. A., Gille, J. C., Kaufman, Y. J., Pétron, G., Yurganov, L. N., Giglio, L., Deeter, M. N., and Yudin, V.: Observations of carbon monoxide and aerosols from the Terra satellite: Northern Hemisphere variability, J. Geophys. Res.-Atmos., 109, D24202, https://doi.org/10.1029/2004jd004727, 2004.

Edwards, D. P., Emmons, L. K., Gille, J. C., Chu, A., Attié, J.-L., Giglio, L., Wood, S. W., Haywood, J., Deeter, M. N., Massie, S. T., Ziskin, D. C., and Drummond, J. R.: Satellite Observed Pollution From Southern Hemisphere Biomass Burning, J. Geophys. Res.-Atmos., 111, D14312, https://doi.org/10.1029/2005JD006655, 2006.

Edwards, D. P., Arellano, A. F., and Deeter, M. N.: A satellite observation system simulation experiment for carbon monoxide in the lowermost troposphere, J. Geophys. Res.-Atmos., 114, D14304, https://doi.org/10.1029/2008JD011375, 2009.

Emmons, L. K., Edwards, D. P., Deeter, M. N., Gille, J. C., Campos, T., Nédélec, P., Novelli, P., and Sachse, G.: Measurements of Pollution In The Troposphere (MOPITT) validation through 2006, Atmos. Chem. Phys., 9, 1795-1803, https://doi.org/10.5194/acp9-1795-2009, 2009.

Fann, N., Lamson, A. D., Anenberg, S. C., Wesson, K., Risley, D., and Hubbell, B. J.: Estimating the National Public Health Burden Associated with Exposure to Ambient $\mathrm{PM}_{2.5}$ and Ozone, Risk Anal., 32, 81-95, https://doi.org/10.1111/j.15396924.2011.01630.x, 2012.

Fisher, J. A., Jacob, D. J., Purdy, M. T., Kopacz, M., Le Sager, P., Carouge, C., Holmes, C. D., Yantosca, R. M., Batchelor, R. L., Strong, K., Diskin, G. S., Fuelberg, H. E., Holloway, J. S., Hyer, E. J., McMillan, W. W., Warner, J., Streets, D. G., Zhang, Q., Wang, Y., and Wu, S.: Source attribution and interannual variability of Arctic pollution in spring constrained by aircraft (ARCTAS, ARCPAC) and satellite (AIRS) observations of carbon monoxide, Atmos. Chem. Phys., 10, 977-996, https://doi.org/10.5194/acp-10-977-2010, 2010.

Fishman, J., Iraci, L. T., Al-Saadi, J., Chance, K., Chavez, F., Chin, M., Coble, P., Davis, C., DiGiacomo, P. M., Edwards, D., Eldering, A., Goes, J., Herman, J., Hu, C., Jacob, D. J., Jordan, C., Kawa, S. R., Key, R., Liu, X., Lohrenz, S., Mannino, A., Natraj, V., Neil, D., Neu, J., Newchurch, M., Pickering, K., Salisbury, J., Sosik, H., Subramaniam, A., Tzortziou, M., Wang, J., and Wang, M.: The United States' Next Generation of Atmospheric Composition and Coastal Ecosystem Measurements: NASA's Geostationary Coastal and Air Pollution Events (GEO-CAPE) Mission, B. Am. Meteorol. Soc., 93, 1547-1566, https://doi.org/10.1175/bams-d-11-00201.1, 2012.

Flynn, L., Long, C., Wu, X., Evans, R., Beck, C. T., Petropavlovskikh, I., McConville, G., Yu, W., Zhang, Z., Niu, J., and Beach, E.: Performance of the Ozone Mapping and Profiler Suite (OMPS) products, J. Geophys. Res.-Atmos., 119, 61816195, https://doi.org/10.1002/2013JD020467, 2014.

Fortems-Cheiney, A., Chevallier, F., Pison, I., Bousquet, P., Szopa, S., Deeter, M. N., and Clerbaux, C.: Ten years of CO emissions as seen from Measurements of Pollution in the Troposphere (MOPITT), J. Geophys. Res.-Atmos., 116, D05304, https://doi.org/10.1029/2010JD014416, 2011.
Frankenberg, C., Meirink, J. F., van Weele, M., Platt, U., and Wagner, T.: Assessing Methane Emissions from Global Space-Borne Observations, Science, 308, 1010-1014, https://doi.org/10.1126/science.1106644, 2005.

Frankenberg, C., Aben, I., Bergamaschi, P., Dlugokencky, E. J., van Hees, R., Houweling, S., van der Meer, P., Snel, R., and Tol, P.: Global column averaged methane mixing ratios from 2003 to 2009 as derived from SCIAMACHY: Trends and variability, J. Geophys. Res.-Atmos., 116, D04302, https://doi.org/10.1029/2010JD014849, 2011.

Galmarini, S., Koffi, B., Solazzo, E., Keating, T., Hogrefe, C., Schulz, M., Benedictow, A., Griesfeller, J. J., JanssensMaenhout, G., Carmichael, G., Fu, J., and Dentener, F.: Technical note: Coordination and harmonization of the multi-scale, multi-model activities HTAP2, AQMEII3, and MICS-Asia3: simulations, emission inventories, boundary conditions, and model output formats, Atmos. Chem. Phys., 17, 1543-1555, https://doi.org/10.5194/acp-17-1543-2017, 2017.

Gambacorta, A., Barnet, C., Wolf, W., King, T., Maddy, E., Strow, L., Xiong, X., Nalli, N., and Goldberg, M.: An Experiment Using High Spectral Resolution CrIS Measurements for Atmospheric Trace Gases: Carbon Monoxide Retrieval Impact Study, IEEE Geosci. Remote S., 11, 1639-1643, 2014.

Garnett, J. D., Farris, M. C., Wong, S. S., Zandian, M., Hall, D. N., Jacobson, S., Luppino, G., Parker, S., Dorn, D., Franka, S., and Freymiller, E.: $2 \mathrm{Kx} 2 \mathrm{~K}$ molecular beam epitaxy $\mathrm{HgCdTe}$ detectors for the James Webb Space Telescope NIRCam instrument, Proceedings of SPIE, 5499, 35-46, 2004.

Gaubert, B., Arellano, A. F., Barré, J., Worden, H. M., Emmons, L. K., Tilmes, S., Buchholz, R. R., Vitt, F., Raeder, K., Collins, N., and Anderson, J. L.: Toward a chemical reanalysis in a coupled chemistry-climate model: An evaluation of MOPITT $\mathrm{CO}$ assimilation and its impact on tropospheric composition, J. Geophys. Res.-Atmos., 121, 7310-7343, https://doi.org/10.1002/2016JD024863, 2016.

George, M., Clerbaux, C., Hurtmans, D., Turquety, S., Coheur, P.F., Pommier, M., Hadji-Lazaro, J., Edwards, D. P., Worden, H., Luo, M., Rinsland, C., and McMillan, W.: Carbon monoxide distributions from the IASI/METOP mission: evaluation with other space-borne remote sensors, Atmos. Chem. Phys., 9, 8317-8330, https://doi.org/10.5194/acp-9-8317-2009, 2009.

Gloudemans, A. M. S., Schrijver, H., Hasekamp, O. P., and Aben, I.: Error analysis for $\mathrm{CO}$ and $\mathrm{CH}_{4}$ total column retrievals from SCIAMACHY $2.3 \mu \mathrm{m}$ spectra, Atmos. Chem. Phys., 8, 39994017, https://doi.org/10.5194/acp-8-3999-2008, 2008.

GMES-GAS: Global Monitoring for Environment and Security Atmosphere Core Service (GACS), in: Implementation Group - Final Report, available at: http://www gmes.info/pages-principales/library/implementation-groups/ gmes-atmosphere-core-service/ (last access: 30 March 2017), 2009.

Green, R. O., Pieters, C., Mouroulis, P., Eastwood, M., Boardman, J., Glavich, T., Isaacson, P., Annadurai, M., Besse, S., Barr, D., and Buratti, B.: The Moon Mineralogy Mapper $\left(\mathrm{M}^{3}\right)$ imaging spectrometer for lunar science: Instrument description, calibration, on-orbit measurements, science data calibration and on-orbit validation, J. Geophys. Res.-Planet., 116, E00G19, https://doi.org/10.1029/2011JE003797, 2011. 
Grell, G., Peckham, S., Schmitz, R., McKeen, S., Frost, G., Skamarock, W., and Eder, B.: Fully coupled "online" chemistry within the WRF model, Atmos. Environ., 39, 6957-6975, https://doi.org/10.1016/j.atmosenv.2005.04.027, 2005.

Guizar-Sicairos, M., Thurman, S. T., and Fienup, J. R.: Efficient subpixel image registration algorithms, Opt. Lett., 33, 156-158, https://doi.org/10.1364/ol.33.000156, 2008.

He, H., Stehr, J. W., Hains, J. C., Krask, D. J., Doddridge, B. G., Vinnikov, K. Y., Canty, T. P., Hosley, K. M., Salawitch, R. J., Worden, H. M., and Dickerson, R. R.: Trends in emissions and concentrations of air pollutants in the lower troposphere in the Baltimore/Washington airshed from 1997 to 2011, Atmos. Chem. Phys., 13, 7859-7874, https://doi.org/10.5194/acp13-7859-2013, 2013.

Heidinger, A.: ABI Cloud Mask Algorithm Theoretical Basis Document, NOAA, available at: http://www.goes-r.gov/products/ ATBDs/baseline/Cloud_CldMask_v2.0_no_color.pdf (last access: 8 December 2017), 2011.

Hess, M., Koepke, P., and Schult, I.: Optical properties of aerosols and clouds: The software package OPAC, B. Am. Meteorol. Soc., 79, 831-844, 1998.

Holloway, T., Levy, H., and Kasibhatla, P.: Global distribution of carbon monoxide, J. Geophys. Res.-Atmos., 105, 12123-12147, https://doi.org/10.1029/1999JD901173, 2000.

Howard, T., Ferrara, T. W., and Townsend-Small, A.: Sensor transition failure in the high flow sampler: Implications for methane emission inventories of natural gas infrastructure, J. Air Waste Manage., 65, 856-862, https://doi.org/10.1080/10962247.2015.1025925, 2015.

Huang, M., Bowman, K. W., Carmichael, G. R., Pierce, R. B., Worden, H. M., Luo, M., Cooper, R., Pollack, I. B., Ryerson, T. B., and Brown, S. S.: Impact of Southern California anthropogenic emissions on ozone pollution in the mountain states: Model analysis and observational evidence from space, J. Geophys. Res.-Atmos., 118, 12784-12803, https://doi.org/10.1002/2013JD020205, 2013.

Hudman, R. C., Murray, L. T., Jacob, D. J., Millet, D. B., Turquety, S., Wu, S., Blake, D. R., Goldstein, A. H., Holloway, J., and Sachse, G. W.: Biogenic versus anthropogenic sources of CO in the United States, Geophys. Res. Lett., 35, L04801, https://doi.org/10.1029/2007gl032393, 2008 .

IGACO: The changing atmosphere: An Integrated Global Atmospheric Chemistry Observation theme for the IGOS partnership. ESA SP-1282, GAW Rep. 159, WMO TD-1235, 72 pp., available at: https://library.wmo.int/pmb_ged/wmo-td_1235.pdf (last access: 10 December 2017), 2004

Ingmann, P., Veihelmann, B., Langen, J., Lamarre, D., Stark, H., and Courrèges-Lacoste, G. B.: Requirements for the GMES Atmosphere Service and ESA's implementation concept: Sentinels4/-5 and-5p, Remote Sens. Environ., 120, 58-69, 2012.

Jacob, D. J., Turner, A. J., Maasakkers, J. D., Sheng, J., Sun, K., Liu, X., Chance, K., Aben, I., McKeever, J., and Frankenberg, C.: Satellite observations of atmospheric methane and their value for quantifying methane emissions, Atmos. Chem. Phys., 16, 14371-14396, https://doi.org/10.5194/acp-16-143712016, 2016.

Jiang, Z., Jones, D. B. A., Worden, H. M., Deeter, M. N., Henze, D. K., Worden, J., Bowman, K. W., Brenninkmeijer, C. A. M., and Schuck, T. J.: Impact of model errors in con- vective transport on $\mathrm{CO}$ source estimates inferred from MOPITT CO retrievals, J. Geophys. Res.-Atmos., 118, 2073-2083, https://doi.org/10.1002/jgrd.50216, 2013.

Jiang, Z., Jones, D. B. A., Worden, J., Worden, H. M., Henze, D. K., and Wang, Y. X.: Regional data assimilation of multispectral MOPITT observations of CO over North America, Atmos. Chem. Phys., 15, 6801-6814, https://doi.org/10.5194/acp15-6801-2015, 2015.

Karion, A., Sweeney, C., Pétron, G., Frost, G., Hardesty, R. M., Kofler, J., Miller, B. R., Newberger, T., Wolter, S., Banta, R., Brewer, A., Dlugokencky, E., Lang, P., Montzka, S. A., Schnell, R., Tans, P., Trainer, M., Zamora, R., and Conley, S.: Methane emissions estimate from airborne measurements over a western United States natural gas field, Geophys. Res. Lett., 40, 43934397, https://doi.org/10.1002/grl.50811, 2013.

Katzenstein, A. S., Doezema, L. A., Simpson, I. J., Blake, D. R., and Rowland, F. S.: Extensive regional atmospheric hydrocarbon pollution in the southwestern United States, P. Natl. Acad. Sci. USA, 100, 11975-11979, https://doi.org/10.1073/pnas.1635258100, 2003.

Kopacz, M., Jacob, D. J., Henze, D. K., Heald, C. L., Streets, D. G., and Zhang, Q.: Comparison of adjoint and analytical Bayesian inversion methods for constraining Asian sources of carbon monoxide using satellite (MOPITT) measurements of CO columns, J. Geophys. Res.-Atmos., 114, 1-10, 2009.

Kopacz, M., Jacob, D. J., Fisher, J. A., Logan, J. A., Zhang, L., Megretskaia, I. A., Yantosca, R. M., Singh, K., Henze, D. K., Burrows, J. P., Buchwitz, M., Khlystova, I., McMillan, W. W., Gille, J. C., Edwards, D. P., Eldering, A., Thouret, V., and Nedelec, P.: Global estimates of CO sources with high resolution by adjoint inversion of multiple satellite datasets (MOPITT, AIRS, SCIAMACHY, TES), Atmos. Chem. Phys., 10, 855-876, https://doi.org/10.5194/acp-10-855-2010, 2010.

Kort, E. A., Eluszkiewicz, J., Stephens, B. B., Miller, J. B., Gerbig, C., Nehrkorn, T., Daube, B. C., Kaplan, J. O., Houweling, S., and Wofsy, S. C.: Emissions of $\mathrm{CH}_{4}$ and $\mathrm{N}_{2} \mathrm{O}$ over the United States and Canada based on a receptor-oriented modeling framework and COBRA-NA atmospheric observations, Geophys. Res. Lett., 35, L18808, https://doi.org/10.1029/2008g1034031, 2008.

Kumer, J. B., Rairden, R. L., Roche, A. E., Chevallier, F., Rayner, P. J., and Moore III, B.: Progress in development of Tropospheric Infrared Mapping Spectrometers (TIMS): geoCARB greenhouse gas (GHG) application, in: Proceedings of the SPIE, 2013, 88670K, https://doi.org/10.1117/12.2022668, 2013.

Lee, S., Hong, Y., Song, C. K., Lee, J., Choi, W. J., Kim, D., Moon, K. J., and Kim, J.: Plan of Korean Geostationary Environment Satellite over Asia- Pacific region, in: EGU General Assembly 2010, Vienna, Austria, 2010.

Levelt, P. F., van den Oord, G. H., Dobber, M. R., Malkki, A., Visser, H., de Vries, J., Stammes, P., Lundell, J. O., and Saari, H.: The ozone monitoring instrument, IEEE T. Geosci. Remote, 44, 1093-1101, https://doi.org/10.1109/TGRS.2006.872333, 2006.

Levi, A, Simonds, J., and Gruber, C.: CHIRP Technology Demonstration Project, in: AIAA Space 2011 Conference and Exposition, 27-29 September 2011, Long Beach, California, USA, https://doi.org/10.2514/6.2011-7333, 2011.

Loomis, D., Grosse, Y., Lauby-Secretan, B., El Ghissassi, F., Bouvard, V., Benbrahim-Tallaa, L., Guha, N., Baan, R., Mattock, H., and Straif, K.: The carcinogenicity of outdoor air pollution, 
Lancet Oncol., 14, 1262-1263, https://doi.org/10.1016/s14702045(13)70487-X, 2013.

Ludwig, C. B., Malkmus, W., Griggs, M., and Bartle, E. R.: Monitoring of Air Pollution by Satellites (MAPS), phase 1, NASA Contractor Report, NASA- CR-112137, 195 pp., available at: https://ntrs.nasa.gov/archive/nasa/casi.ntrs. nasa.gov/19730008955.pdf (last access: 14 February 2018), 1972.

Malley, C. S., Kuylenstierna, J. C., Vallack, H. W., Henze, D. K., Blencowe, H., and Ashmore, M. R.: Preterm birth associated with maternal fine particulate matter exposure: A global, regional and national assessment, Environ. Int., 101, 173-182, https://doi.org/10.1016/j.envint.2017.01.023, 2017.

Massie, S. T., Gille, J. C., Edwards, D. P., and Nandi, S.: Satellite observations of aerosol and CO over Mexico City, Atmos. Environ., 40, 6019-6031, https://doi.org/10.1016/j.atmosenv.2005.11.065, 2006.

Matsunaga, T., Maksyutov, S., Morino, I., Yoshida, Y., Saito, M., Noda, H., Kamei, A., Kawazoe, F., and Yokot, T.: Recent Progress in NIES GOSAT and GOSAT-2 Projects, presented at 13th International Workshop on Greenhouse Gas Measurements from Space, Helsinki, Finland, 6-8 June 2017, available at: http://iwggms13.fmi.fi/presentations/j06_s01_02_ Matsunaga.pdf, last access: 30 March 2017.

Meirink, J. F., Bergamaschi, P., Frankenberg, C., d'Amelio, M. T., Dlugokencky, E. J., Gatti, L. V., Houweling, S., Miller, J. B., Röckmann, T., Villani, M. G., and Krol, M. C.: Fourdimensional variational data assimilation for inverse modeling of atmospheric methane emissions: Analysis of SCIAMACHY observations, J. Geophys. Res.-Atmos., 113, D17301, https://doi.org/10.1029/2007jd009740, 2008.

Miller, S. M., Matross, D. M., Andrews, A. E., Millet, D. B., Longo, M., Gottlieb, E. W., Hirsch, A. I., Gerbig, C., Lin, J. C., Daube, B. C., Hudman, R. C., Dias, P. L. S., Chow, V. Y., and Wofsy, S. C.: Sources of carbon monoxide and formaldehyde in North America determined from high-resolution atmospheric data, Atmos. Chem. Phys., 8, 7673-7696, https://doi.org/10.5194/acp-87673-2008, 2008.

Miller, S. M., Wofsy, S. C., Michalak, A. M., Kort, E. A., Andrews, A. E., Biraud, S. C., Dlugokencky, E. J., Eluszkiewicz, J., Fischer, M. L., Janssens-Maenhout, G., Miller, B. R., Miller, J. B., Montzka, S. A., Nehrkorn, T., and Sweeney, C.: Anthropogenic emissions of methane in the United States, P. Natl. Acad. Sci. USA, 110, 20018-20022, https://doi.org/10.1073/pnas.1314392110, 2013.

MOPITT Science Team: MOPITT/Terra Level 2 CO vertical profiles derived from Near and Thermal Infrared Radiances, version 7, Hampton, VA, USA, NASA Atmospheric Science Data Center (ASDC), https://doi.org/10.5067/TERRA/MOPITT/MOP02J_L2.007 (last access: 20 February 2018), 2013.

Morino, I., Uchino, O., Inoue, M., Yoshida, Y., Yokota, T., Wennberg, P. O., Toon, G. C., Wunch, D., Roehl, C. M., Notholt, J., Warneke, T., Messerschmidt, J., Griffith, D. W. T., Deutscher, N. M., Sherlock, V., Connor, B., Robinson, J., Sussmann, R., and Rettinger, M.: Preliminary validation of column-averaged volume mixing ratios of carbon dioxide and methane retrieved from GOSAT short-wavelength infrared spectra, Atmos. Meas. Tech., 4, 1061-1076, https://doi.org/10.5194/amt-4-1061-2011, 2011.
Myhre, G., Shindell, D., Bréon, F. M., Collins, W., Fuglestvedt, J., Huang, J., Koch, D., Lamarque, J. F., Lee, D., Mendoza, B., and Nakajima, T.: Anthropogenic and Natural Radiative Forcing. The Physical Science Basis. Contribution of Working Group I to the Fifth Assessment Report of the Intergovernmental Panel on Climate Change 2013, Cambridge University Press, Cambridge, UK and New York, USA, available at: http://www.ipcc.ch/pdf/assessment-report/ar5/wg1/ WG1AR5_Chapter08_FINAL.pdf (last access: 30 March 2017), 2013.

National Research Council (NRC): Air Quality Management in the United States, The National Academies Press, Washington, DC, USA, https://doi.org/10.17226/10728, 2004.

National Research Council (NRC): Earth science and applications from space: national imperatives for the next decade and beyond, The National Academies Press, Washington, DC, USA, https://doi.org/10.17226/11820, 2007.

Nédélec P., Blot R., Boulanger D., Athier, G., Cousin, J-M., Gautron, B., Petzold, A., Volz-Thomas, A., and Thouret, V.: Instrumentation on commercial aircraft for monitoring the atmospheric composition on a global scale: the IAGOS system, technical overview of ozone and carbon monoxide measurements, MOZAIC-IAGOS special issue, Tellus B, 67, 27791, https://doi.org/10.3402/tellusb.v67.27791, 2015.

Neil, D. O., Gordley, L. L., Marshall, B. T., and Sachse, G. W.: Tropospheric carbon monoxide measurements from geostationary orbit, in Proceedings of the SPIE 4168, Remote Sensing of Clouds and the Atmosphere V, 2001, 265-273, https://doi.org/10.1117/12.413873, 2001.

O’Brien, D. M., Polonsky, I. N., Utembe, S. R., and Rayner, P. J.: Potential of a geostationary geoCARB mission to estimate surface emissions of $\mathrm{CO}_{2}, \mathrm{CH}_{4}$ and $\mathrm{CO}$ in a polluted urban environment: case study Shanghai, Atmos. Meas. Tech., 9, 4633-4654, https://doi.org/10.5194/amt-9-4633-2016, 2016.

O’Dell, C. W., Connor, B., Bösch, H., O’Brien, D., Frankenberg, C., Castano, R., Christi, M., Eldering, D., Fisher, B., Gunson, M., McDuffie, J., Miller, C. E., Natraj, V., Oyafuso, F., Polonsky, I., Smyth, M., Taylor, T., Toon, G. C., Wennberg, P. O., and Wunch, D.: The ACOS $\mathrm{CO}_{2}$ retrieval algorithm - Part 1: Description and validation against synthetic observations, Atmos. Meas. Tech., 5, 99-121, https://doi.org/10.5194/amt-5-99-2012, 2012.

Palmer, P. I., Suntharalingam, P., Jones, D., Jacob, D. J., Streets, D. G., Fu, Q., Vay, S. A., and Sachse, G. W. Using $\mathrm{CO}_{2}$ : $\mathrm{CO}$ correlations to improve inverse analyses of carbon fluxes, J. Geophys. Res.-Atmos., 111, D12318, https://doi.org/10.1029/2005jd006697, 2006.

Pan, L., Edwards, D. P., Gille, J. C., Smith, M. W., and Drummond, J. R.: Satellite remote sensing of tropospheric $\mathrm{CO}$ and $\mathrm{CH}_{4}$ : forward model studies of the MOPITT instrument, Appl. Optics, 34, 6976-6988, https://doi.org/10.1364/AO.34.006976, 1995.

Payne, V. H., Clough, S. A., Shephard, M. W., Nassar, R., and Logan, J. A.: Information-centered representation of retrievals with limited degrees of freedom for signal: Application to methane from the Tropospheric Emission Spectrometer, J. Geophys. Res.Atmos., 114, D10307, https://doi.org/10.1029/2008JD010155, 2009.

Pechony, O., Shindell, D. T., and Faluvegi, G.: Direct top-down estimates of biomass burning CO emissions using TES and MOPITT 
versus bottom-up GFED inventory, J. Geophys. Res.-Atmos., 118, 8054-8066, https://doi.org/10.1002/jgrd.50624, 2013.

Pétron, G., Frost, G., Miller, B. R., Hirsch, A. I., Montzka, S. A., Karion, A., Trainer, M., Sweeney, C., Andrews, A. E., Miller, L., and Kofler, J.: Hydrocarbon emissions characterization in the Colorado Front Range: A pilot study, J. Geophys. Res.-Atmos., 117, D04304, https://doi.org/10.1029/2011jd016360, 2012.

Pfister, G., Gille, J. C., Ziskin, D., Francis, G., Edwards, D. P., Deeter, M. N., and Abbott, E.: Effects of a Spectral Surface Reflectance on Measurements of Backscattered Solar Radiation: Application to the MOPITT Methane Retrieval, J. Atmos. Ocean. Tech., 22, 566-574, https://doi.org/10.1175/JTECH1721.1, 2005.

Pfister, G. G., Reddy, P., Barth, M. C., Flocke, F. F., Fried, A., Herndon, S. C., Sive, B. C., Sullivan, J. T., Thompson, A. M., Yacovitch, T. I., Weinheimer, A. J., and Wisthaler, A.: Using observations and source specific model tracers to characterize pollutant transport during FRAPPÉ and DISCOVER-AQ, J. Geophys. Res.-Atmos., 122, 10510-10538, https://doi.org/10.1002/2017JD027257, 2017.

Pickett-Heaps, C. A., Jacob, D. J., Wecht, K. J., Kort, E. A., Wofsy, S. C., Diskin, G. S., Worthy, D. E. J., Kaplan, J. O., Bey, I., and Drevet, J.: Magnitude and seasonality of wetland methane emissions from the Hudson Bay Lowlands (Canada), Atmos. Chem. Phys., 11, 3773-3779, https://doi.org/10.5194/acp-113773-2011, 2011.

Polonsky, I. N., O’Brien, D. M., Kumer, J. B., O'Dell, C. W., and the geoCARB Team: Performance of a geostationary mission, geoCARB, to measure $\mathrm{CO}_{2}, \mathrm{CH}_{4}$ and $\mathrm{CO}$ columnaveraged concentrations, Atmos. Meas. Tech., 7, 959-981, https://doi.org/10.5194/amt-7-959-2014, 2014.

Reichle Jr., H. G., Anderson, B. E., Connors, V. S., Denkins, T., Forbes, D. A., Gormsen, B. B., Langenfelds, R. L., Neil, D. O., Nolf, S. R., Novelli, P. C., and Pougatchev, N. S.: Space shuttle based global CO measurements during April and October 1994, MAPS instrument, data reduction, and data validation, J. Geophys. Res.-Atmos., 104, 21443-21454, 1999.

Rodgers, C. D.: Inverse Methods for Atmospheric Sounding - Theory and Practice, Series on Atmospheric Oceanic and Planetary Physics, vol. 2, World Scientific Publishing, Singapore, 2000.

Rodgers, C. D., Wells, R. J., Grainger, R. G., and Taylor, F. W.: Improved stratospheric and mesospheric sounder validation: General approach and in-flight radiometric calibration, J. Geophys. Res.-Atmos., 101, 9775-9793, 1996.

Russell III, J. M., Gordley, L. L., Park, J. H., Drayson, S. R., Hesketh, D. H., Cicerone, R. J., Tuck, A. F., Frederick, J. E., Harries, J. E., and Crutzen, P.: The Halogen Occultation Experiment, J. Geophys. Res.-Atmos., 98, 10777-10797, 1993.

Russell, P. B., Livingston, J. M., Hignett, P., Kinne, S., Wong, J., Chien, A., Bergstrom, R., Durkee, P., and Hobbs, P. V.: Aerosolinduced radiative flux changes off the United States mid-Atlantic coast: Comparison of values calculated from sunphotometer and in situ data with those measured by airborne pyranometer, J. Geophys. Res.-Atmos., 104, 2289-2307, 1999.

Schepers, D., Guerlet, S., Butz, A., Landgraf, J., Frankenberg, C., Hasekamp, O., Blavier, J.-F., Deutscher, N. M., Griffith, D. W. T., Hase, F., Kyro, E., Morino, I., Sherlock, V., Sussmann, R., and Aben, I.: Methane retrievals from Greenhouse Gases Observing Satellite (GOSAT) shortwave infrared measurements: Performance comparison of proxy and physics retrieval algorithms, J. Geophys. Res.-Atmos. 117, D10307, https://doi.org/10.1029/2012JD017549, 2012.

Schneising, O., Burrows, J. P., Dickerson, R. R., Buchwitz, M., Reuter, M., and Bovensmann, H.: Remote sensing of fugitive methane emissions from oil and gas production in North American tight geologic formations, Earth's Future, 2, 548-558, https://doi.org/10.1002/2014ef000265, 2014.

Schwietzke, S., Sherwood, O. A., Bruhwiler, L. M., Miller, J. B. Etiope, G., Dlugokencky, E. J., Michel, S. E., Arling, V. A., Vaughn, B. H., White, J. W., and Tans, P. P.: Upward revision of global fossil fuel methane emissions based on isotope database, Nature, 538, 88-91, https://doi.org/10.1038/nature19797, 2016.

Shindell, D. T., Faluvegi, G., Shindell, D. T., Faluvegi, G., Koch, D. M., Schmidt, G. A., Unger, N., and Bauer, S. E.: Improved attribution of climate forcing to emissions, Science, 326, 716718, https://doi.org/10.1126/science.1174760, 2009.

Silva, S. J., Arellano, A. F., and Worden, H. M.: Toward anthropogenic combustion emission constraints from space-based analysis of urban $\mathrm{CO}_{2} / \mathrm{CO}$ sensitivity, Geophys. Res. Lett., 40, 49714976, https://doi.org/10.1002/grl.50954, 2013.

Simmons, A., Fellous, J. L., Ramaswamy, V., Trenberth, K., Asrar, G., Balmaseda, M., Burrows, J. P., Ciais, P., Drinkwater, M., Friedlingstein, P., and Gobron, N.: Observation and integrated Earth-system science: A roadmap for 2016-2025, Adv. Space Res., 57, 2037-2103, https://doi.org/10.1016/j.asr.2016.03.008, 2016.

Spurr, R. J. D.: VLIDORT: A linearized pseudo-spherical vector discrete ordinate radiative transfer code for forward model and retrieval studies in multilayer multiple scattering media, J. Quant. Spectrosc. Ra., 102, 316-343, https://doi.org/10.1016/j.jqsrt.2006.05.005, 2006.

Tolton, B. T. and Drummond, J. R.: Characterization of the length-modulated radiometer, Appl. Optics, 36, 5409-5420, https://doi.org/10.1364/AO.36.005409, 1997.

Trasande, L., Malecha, P., and Attina, T. M.: Particulate matter exposure and preterm birth: estimates of US attributable burden and economic costs, Environ. Health Persp., 124, 1913, https://doi.org/10.1289/ehp.1510810, 2016.

Turner, A. J., Jacob, D. J., Wecht, K. J., Maasakkers, J. D., Lundgren, E., Andrews, A. E., Biraud, S. C., Boesch, H., Bowman, K. W., Deutscher, N. M., Dubey, M. K., Griffith, D. W. T., Hase, F., Kuze, A., Notholt, J., Ohyama, H., Parker, R., Payne, V. H., Sussmann, R., Sweeney, C., Velazco, V. A., Warneke, T., Wennberg, P. O., and Wunch, D.: Estimating global and North American methane emissions with high spatial resolution using GOSAT satellite data, Atmos. Chem. Phys., 15, 7049-7069, https://doi.org/10.5194/acp-15-7049-2015, 2015.

Turner, M. C., Jerrett, M., Pope III, C.A., Krewski, D., Gapstur, S. M., Diver, W. R., Beckerman, B. S., Marshall, J. D., Su, J., Crouse, D. L., and Burnett, R. T.: Long-term ozone exposure and mortality in a large prospective study, Am. J. Resp. Crit. Care, 193, 1134-1142, https://doi.org/10.1164/rccm.201508-1633OC, 2015.

UNEP: Near-term Climate Protection and Clean Air Benefits: Actions for Controlling Short-Lived Climate Forcers, United Nations Environment Programme (UNEP), Nairobi, Kenya, available at: http://www.ccacoalition.org/en/resources/near-term- 
climate-protection-and-clean-air-benefits-actions-controllingshort-lived (last access: 14 February 2018), 2011.

U.S. Department of Health, Education, and Welfare, Public Health Service, National Air Pollution Control Administration: Air Quality Criteria for Carbon Monoxide, Publication No. AP-62, Washington, D.C., USA, 1970.

U.S. EPA: Federal Implementation Plans: Interstate Transport of Fine Particulate Matter and Ozone and Correction of SIP Approvals, 76 Fed. Reg. 153, Federal Register: The Daily Journal of the United States, 48208-48483, available at: https://www.gpo. gov/fdsys/pkg/FR-2011-08-08/pdf/2011-17600.pdf (last access: 14 February 2018), 2011.

Veefkind, J. P., Aben, I., McMullan, K., Forster, H., de Vries, J., Otter, G., Claas, J., Eskes, H. J., de Haan, J. F., Kleipool, Q., van Weele, M., Hasekamp, O., Hoogeveen, R., Landgraf, J., Snel, R., Tol, P., Ingmann, P., Voors, R., Kruizinga, B., Vink, R., Visser, H., and Levelt, P. F.: TROPOMI on the ESA Sentinel-5 Precursor: A GMES mission for global observations of the atmospheric composition for climate, air quality and ozone layer applications, Remote Sens. Environ., 120, 70-83, https://doi.org/10.1016/j.rse.2011.09.027, 2012.

Vey, S., Dietrich, R., Rülke, A., Fritsche, M., Steigenberger, P., and Rothacher, M.: Validation of Precipitable Water Vapor within the NCEP/DOE Reanalysis Using Global GPS Observations from One Decade, J. Climate, 23, 1675-1695, 2010.

Vijayaraghavan, K., Snell, H. E., and Seigneur, C.: Practical Aspects of Using Satellite Data in Air Quality Modeling, Environ. Sci. Technol., 42, 8187-8192, https://doi.org/10.1021/es7031339, 2008.

Warner, J. X., Gille, J. C., Edwards, D. P., Ziskin, D. C., Smith, M. W., Bailey, P. L., and Rokke, L.: Cloud Detection and Clearing for the Earth Observing System Terra Satellite Measurements of Pollution in the Troposphere (MOPITT) Experiment, Appl. Optics, 40, 1269-1284, https://doi.org/10.1364/AO.40.001269, 2001.

Wecht, K. J., Jacob, D. J., Sulprizio, M. P., Santoni, G. W., Wofsy, S. C., Parker, R., Bösch, H., and Worden, J.: Spatially resolving methane emissions in California: constraints from the CalNex aircraft campaign and from present (GOSAT, TES) and future (TROPOMI, geostationary) satellite observations, Atmos. Chem. Phys., 14, 8173-8184, https://doi.org/10.5194/acp-148173-2014, 2014a.

Wecht, K. J., Jacob, D. J., Frankenberg, C., Jiang, Z., and Blake, D. R.: Mapping of North American methane emissions with high spatial resolution by inversion of SCIAMACHY satellite data, J. Geophys. Res.-Atmos., 119, 77417756, https://doi.org/10.1002/2014JD021551, 2014b.

West, J. J., Fiore, A. M., Horowitz, L. W., and Mauzerall, D. L.: Global health benefits of mitigating ozone pollution with methane emission controls, P. Natl. Acad. Sci. USA, 103, 39883993, https://doi.org/10.1073/pnas.0600201103, 2006.

Westerling, A. L., Hidalgo, H. G., Cayan, D. R., and Swetnam, T. W.: Warming and earlier spring increase western US forest wildfire activity, Science, 313, 940-943, https://doi.org/10.1126/science.1128834, 2006.

Worden, H. M., Deeter, M. N., Edwards, D. P., Gille, J. C., Drummond, J. R., and Nédélec, P.: Observations of nearsurface carbon monoxide from space using MOPITT mul- tispectral retrievals, J. Geophys. Res.-Atmos., 115, D18314, https://doi.org/10.1029/2010JD014242, 2010.

Worden, H. M., Cheng, Y., Pfister, G., Carmichael, G. R., Zhang, Q., Streets, D. G., Deeter, M., Edwards, D. P., Gille, J. C., and Worden, J. R.: Satellite-based estimates of reduced $\mathrm{CO}$ and $\mathrm{CO}_{2}$ emissions due to traffic restrictions during the 2008 Beijing Olympics, Geophys. Res. Lett., 39, L14802, https://doi.org/10.1029/2012GL052395, 2012.

Worden, H. M., Deeter, M. N., Frankenberg, C., George, M., Nichitiu, F., Worden, J., Aben, I., Bowman, K. W., Clerbaux, C., Coheur, P. F., de Laat, A. T. J., Detweiler, R., Drummond, J. R., Edwards, D. P., Gille, J. C., Hurtmans, D., Luo, M., Martínez-Alonso, S., Massie, S., Pfister, G., and Warner, J. X.: Decadal record of satellite carbon monoxide observations, Atmos. Chem. Phys., 13, 837-850, https://doi.org/10.5194/acp-13837-2013, 2013.

Worden, J., Wecht, K., Frankenberg, C., Alvarado, M., Bowman, K., Kort, E., Kulawik, S., Lee, M., Payne, V., and Worden, $\mathrm{H}$.: $\mathrm{CH}_{4}$ and $\mathrm{CO}$ distributions over tropical fires during October 2006 as observed by the Aura TES satellite instrument and modeled by GEOS-Chem, Atmos. Chem. Phys., 13, 3679-3692, https://doi.org/10.5194/acp-13-3679-2013, 2013a.

Worden, J., Jiang, Z., Jones, D., Alvarado, M., Bowman, K., Frankenberg, C., Kort, E. A., Kulawik, S. S., Lee, M., Liu, J., and Payne, V.: El Niño, the 2006 Indonesian peat fires, and the distribution of atmospheric methane, Geophys. Res. Lett., 40, 49384943, https://doi.org/10.1002/grl.50937, 2013b.

Wunch, D., Toon, G. C., Wennberg, P. O., Wofsy, S. C., Stephens, B. B., Fischer, M. L., Uchino, O., Abshire, J. B., Bernath, P., Biraud, S. C., Blavier, J.-F. L., Boone, C., Bowman, K. P., Browell, E. V., Campos, T., Connor, B. J., Daube, B. C., Deutscher, N. M., Diao, M., Elkins, J. W., Gerbig, C., Gottlieb, E., Griffith, D. W. T., Hurst, D. F., Jiménez, R., Keppel-Aleks, G., Kort, E. A., Macatangay, R., Machida, T., Matsueda, H., Moore, F., Morino, I., Park, S., Robinson, J., Roehl, C. M., Sawa, Y., Sherlock, V., Sweeney, C., Tanaka, T., and Zondlo, M. A.: Calibration of the Total Carbon Column Observing Network using aircraft profile data, Atmos. Meas. Tech., 3, 1351-1362, https://doi.org/10.5194/amt-3-1351-2010, 2010.

Xiao, Y., Logan, J. A., Jacob, D. J., Hudman, R. C., Yantosca, R., and Blake, D. R.,: Global budget of ethane and regional constraints on US sources, J. Geophys. Res.-Atmos., 113, D21306, https://doi.org/10.1029/2007jd009415, 2008.

Zhang, L., Jacob, D. J., Bowman, K. W., Logan, J. A., Turquety, S., Hudman, R. C., Li, Q., Beer, R., Worden, H. M., Worden, J. R., and Rinsland, C. P.: Ozone-CO correlations determined by the TES satellite instrument in continental outflow regions, Geophys. Res. Lett., 33, L18804, https://doi.org/10.1029/2006g1026399, 2006.

Zoogman, P., Jacob, D. J., Chance, K., Worden, H. M., Edwards, D. P., and Zhang, L.: Improved monitoring of surface ozone by joint assimilation of geostationary satellite observations of ozone and CO, Atmos. Environ., 84, 254-261, https://doi.org/10.1016/j.atmosenv.2013.11.048, 2014.

Zoogman, P., Liu, X., Suleiman, R. M., Pennington, W. F, Flittner, D. E., Al-Saadi, J. A., Hilton, B. B., Nicks, D. K., Newchurch, M. J., Carr, J. L., Janz, S. J., Andraschko, M. R., Arola, A., Baker, B. D., Canova, B. P., Chan Miller, C., Cohen, R. C., Davis, J. E., Dussault, M. E., Edwards, D. P., Fishman, J., González Abad, G., 
Grutter, M., Herman, J. R., Houck, J., Jacob, D. J., Joiner, J., Kerridge, B. J., Kim, J., Krotkov, N. A., Lamsal, L., Lif, C., Lindfors, A., Martin, R. V., McElroy, C. T., McLinden, C., Natraj, V., Neil, D. O., Nowlan, C. R., O’Sullivan, E. J., Palmer, P. I., Pierce, R. B., Pippin, M. R., Saiz-Lopez, A., Spurr, R. J. D., Szykman, J. J., Torres, O., Veefkind, J. P., Veihelmanna, B., Wang, H., Wang, J., Ghula, A., and Chance, K.: Tropospheric Emissions: Monitoring of Pollution (TEMPO), J. Quant. Spectrosc. Ra., 186, 17-39, https://doi.org/10.1016/j.jqsrt.2016.05.008, 2017. 